\title{
Morphological Convergence in Forest Microfungi Provides a Proxy for Paleogene Forest Structure
}

\section{Rikkinen, Jouko Kalevi}

Academic Press

2018-07-27

Rikkinen , J K \& Schmidt , A 2018 , Morphological Convergence in Forest Microfungi Provides a Proxy for Paleogene Forest Structure . in M Krings , C J Harper , N R Cúneo \& G W Rothwell (eds), Transformative Paleobotany : Papers to Commemorate the Life and Legacy of Thomas N. Taylor . 1 edn , Academic Press , London , pp. 527-549 . https://doi.org/10.1016/B978-0-12-81

http://hdl.handle.net/10138/309519

https://doi.org/10.1016/B978-0-12-813012-4.00022-X

unspecified

acceptedVersion

Downloaded from Helda, University of Helsinki institutional repository.

This is an electronic reprint of the original article.

This reprint may differ from the original in pagination and typographic detail.

Please cite the original version. 


\title{
Chapter 22
}

\section{Morphological Convergence in Forest Microfungi Provides a Proxy for Paleogene Forest Structure}

\author{
Jouko Rikkinen and Alexander R. Schmidt
}

\section{INTRODUCTION}

Amber, fossilized plant resin from gymnosperms and angiosperms, is renowned for preserving a wide range of organisms in microscopic fidelity. These so-called amber inclusions comprise many groups of organisms, ranging frombacteria to arthropods and vertebrates (Penney, 2010; Ragazzi and Schmidt, 2011;Grimaldi and Ross, 2017). Organisms trapped in amber typically derive from forest ecosystems where they became stuck to resin outpourings in their habitats (Seyfullah and Schmidt, 2015). In addition, ambers are prime examples of chemical fossils that are relatively resistant to diagenesis and can retain their original chemical and isotopic compositions. Therefore, chemical profiles of ambers may support the detection of the resin-bearing plants and the reconstruction of the paleoenvironment and paleoclimate (Langenheim, 2003; Dal Corso et al., 2017). The study of amber and its inclusions should consequently enable the reconstruction of past forest ecosystems and even prevailing climatic conditions.

However, several constraints exist for this approach. Much amber from the hundreds of worldwide localities does not contain notable inclusions or predominantly preserved arthropods, prokaryotes, and fungal mycelia (Martınez-Delclòs et al., 2004; Labandeira, 2014). Arthropods are indeed the most commonly studied amber inclusions, whereas fossil plant remains and palynomorphs, on which reconstructions of Cenozoic forests and derived climate estimates are typically based on (Ferguson et al., 1998; Bruch and Mosbrugger, 2002; Kunzmann and Walther, 2012), are relatively rare in amber. Only six worldwide amber deposits harbor plenty of plant inclusions, so far: Miocene Dominican and Mexican ambers, Paleogene Baltic, Bitterfeld, and Rovno ambers, and mid-Cretaceous Burmese amber (Penney, 2010).

Further hurdles are linked to the physical properties of amber. Once reworked from the original sediment, amber may float or drift in sea water, and the notion exists that even amber specimens forming large deposits may have been reworked and transported, originally belonging to older and possibly geographically distinct sediments (Weitschat and Wichard, 2010).

Baltic and Bitterfeld ambers constitute the largest Paleogene amber deposits worldwide, with estimated 640,000 tons of fossil resin for the Baltic deposit (Weitschat and Wichard, 2010) and approximately 3000 tons for the central German Bitterfeld locality (Liehmann, 2013). Hundreds of thousands of inclusions were found in Baltic amber, with $>3000$ species described from Baltic amber (Weitschat and Wichard, 2010) and $>700$ species reported from Bitterfeld amber (Rappsilber, 2016).

Uncertainties regarding botanical provenance, age, and geographical origin are particularly associated with these two amber deposits. Langenheim (2003) introduced the term "Tertiary Baltic Amber Mystery" to refer to the conflicting evidence about the botanical source of succinite, which is the main resin variety of Baltic 
and Bitterfeld amber. Suggested source plants of succinite include representatives of the Araucariaceae, Cupressaceae, Pinaceae, and Sciadopityaceae (Langenheim, 2003; Yamamoto et al., 2006; Wolfe et al., 2009; Seyfullah et al., 2018).

Baltic amber primarily derives from the marine Blue Earth layer that is predominantly exposed on the Samland Peninsula northwest of Kaliningrad (Russia) and contiguous areas. Baltic amber eroded from sediments is also frequently found washed ashore along the coast of the Baltic Sea, particularly on the Samland Peninsula and in the Baltic States, Poland, Denmark, Germany, and southern Sweden (Standke, 2008; Weitschat and Wichard, 2010). The absolute age of Baltic amber is still under debate. Palynological data suggest an upper Eocene (Priabonian) age (c. 38e34 million years) of the Blue Earth (Kosmowska-Ceranowicz et al., 1997; Standke, 1998, 2008). Fewer amounts of amber also occur in Lutetian (middle Eocene) sediments including the Lower Blue Earth and even in the upper Oligocene Lower Gestreifter Sand, leading to a possible age range of approximately 47e 24 million years before present for all Baltic amber-bearing strata (Kosmowska-Ceranowicz et al., 1997; Standke, 1998, 2008; Kasinski and Kramarska, 2008).

The frequently cited Lutetian age of the Blue Earth was originally suggested by Ritzkowski (1997), who dated glauconites from the amber-bearing layer. However, Clauer et al. (2005) showed that the applied dating methods can lead to older age estimates if the glauconites have been reworked or if nonglauconized detrital mica contaminated the glauconite splits. Redeposition of the Baltic amber into the Blue Earth layer has also been suggested (Weitschat and Wichard, 2010). However, typical signs of erosion which normally occur if amber has been reworked, such as "pebble-shaped" amber pieces or a dark oxidized crust, are absent in the material from the Blue Earth layer. The majority of amber from the Blue Earth is rather of a fresh lemon yellow color and unoxidized (Grimaldi and Ross, 2017). Bitterfeld amber derives from the Goitzsche open cast mine near the city of Bitterfeld in central Germany where it was mined from the 1970s to the 1990s (Liehmann, 2013). The amberbearing sediment of this locality is the Bernsteinschluff Horizon, located in the upper part of the Cottbus Formation, and it has been dated as upper Oligocene with an absolute age of 25.3-23.8 million years (Knuth et al., 2002; Blumenstengel, 2004). A notion that Bitterfeld amber represents redeposited Eocene Baltic amber is based on the significant proportion of identical arthropod morphologies in amber from both localities (Weitschat, 1997). However, redeposition of Baltic amber is unlikely based on the reconstruction of the sedimentary environment of this amber deposit (Standke, 2008). In addition, chemical differences have been detected between Baltic and Bitterfeld succinite (Yamamoto et al., 2006; Vávra, 2008), and more additional resin types occur in the Bitterfeld area, compared with the Baltic region (Kosmowska-Ceranowicz and Vávra, 2015), which makes an identical provenance unlikely. A local reworking of pre- Chattian amber, however, has not been dispelled so far (see Dunlop, 2010 and Wolfe et al., 2016, for discussion). In any case, Bitterfeld amber is Paleogene in age and its minimum age is approximately 24 million years.

Given these uncertainties, assumptions about forest composition, forest structure and climate of the source area of these ambers vary considerably, depending on the assumed age, origin and source plants (Sadowski et al., 2017). The search for amber inclusions that are indicative for certain forest types and forest structures is a logical consequence (Kaasalainen et al., 2017; Sadowski et al., 2017).

Inclusions of filamentous fungi are common in amber from many deposits around the world (Beimforde and Schmidt, 2011). However, in most cases, only vegetative mycelia are preserved without any reproductive 
structures. As the accurate taxonomic assignment of such specimens is usually impossible, relatively few amberpreserved fungal fossils have so far been assigned to extant lineages (Beimforde et al., 2014; Kettunen et al., 2015, 2018). However, recent studies have demonstrated that European Paleogene amber is a valuable source of fossils in some taxonomic and ecological groups within the Ascomycota. Such findings have already provided valuable new insights into the diversity and evolutionary history of sooty molds (Schmidt et al., 2014), lichensymbiotic and lichenassociated fungi (Hartl et al., 2015; Kaasalainen et al., 2015, 2017; Kettunen et al., 2016, 2017), and calicioid lichens and fungi (Rikkinen and Poinar, 2000; Rikkinen, 2003b; Tuovila et al., 2013; Rikkinen et al., 2018).

Calicioid lichens and fungi, which are from now on referred to as "calicioids," constitute a diverse group of tiny ascomycetes with superficially similar, usually well-stalked ascomata and which often accumulate mature ascospores on top of the apothecial disk to form a true mazaedium (Plates I, II, and III). Because the ascospores of most calicioids are dark, the mazaedium stains the finger if touched. The Finnish term for calicioids (nokinuppinen) is a diminutive of "smut-knob," which accurately describes the smearing property of the persisting spore mass. Calicioids include both lichen-symbiotic, parasitic and saprotrophic species and include genera from several classes of Ascomycota. The polyphyletic nature of the group was first demonstrated by Tibell (1984) on morphological grounds and has since been confirmed in many molecular studies (Wedin and Tibell, 1997; Tibell and Wedin, 2000; Wedin et al., 2000, 2002; Tibell, 2003; Hibbett et al., 2007; Prieto et al., 2013; Prieto and Wedin, 2013, 2017; Beimforde et al., 2014; van den Broeck et al., 2017). Traditionally, Sphaerophorus Pers. and some other genera of fruticose macrolichens with mazaediate apothecia also were included in "calicioid lichens." However, as their morphology, size, and ecology differ drastically from those of crustose species, they are not discussed further here.

The aim of this study is to use all available information on the morphology and ecology of extant calicioids to reconstruct the substrate and habitat ecology of known fossil calicioids and then to use this information to open new insights into the stand structure and ecological conditions of European Paleogene amber forests. First, we introduce the morphology of extant calicioids and demonstrate that their structural features are intimately linked to habitat ecology and are instrumental for successful dispersal; we also explain the conspicuous morphological convergence between phylogenetically distant calicioid fungi. Then, we show that the adaptive traits of calicioids have not changed since at least the Eocene, and argue that their fundamental niches also have remained unchanged. Finally, we summarize what the diversity and relative abundance of fossil calicioids in amber tells us about the ecological conditions that once prevailed in European amber forests.

\section{MORPHOLOGY, DISTRIBUTION, AND ECOLOGY OF EXTANT CALICIOIDS}

\subsection{Morphology and Anatomy}

Most nonlichenized calicioids have immersed mycelia and produce ascomata only on the surface of their substrate. While the vegetative thalli of some calicioid lichens also are endosubstratic, most of them produce episubstratic crustose thalli (Plate I). Depending on the species, the thallus can be smooth, squamulose, 
verrucose, granular, or farinaceous, and in some species, the structure of the thallus is partly determined by growth conditions.

The most conspicuous features of calicioids are the upright ascomata, which are invariably produced on the substrate surface (Plates I, II, and III). The size and shape of ascomata vary between different genera and species as can be expected in light of the highly polyphyletic nature of the group. In several genera, the ascomata are always stalked, while in others, they can be either stalked or sessile or always sessile. Even when mature, the ascomata are small, typically $<1.2 \mathrm{~mm}$ high, and sometimes tiny, only $0.1-0.3 \mathrm{~mm}$ high. The stalks of some resinicolous species can rarely elongate to $20 \mathrm{~mm}$ or even more, and in many cases the stalk length is quite variable and partly dependent on the environment (Yahr, 2015). The outermost stalk hyphae of all extant Chaenotheca (Th. Fr.) Th. Fr. (Coniocybaceae, Coniocybomycetes) and Phaeocalicium A.F.W. Schmidt (Mycocaliciaceae, Eurotiomycetes) are periclinally arranged, while those of Calicium Pers. (Caliciaceae, Lecanoromycetes) and Chaenothecopsis Vain. (Mycocaliciaceae, Eurotiomycetes) are irregularly arranged. The excipulum surface is usually formed by isodiametric cells in Calicium, while those of Chaenotheca, Chaenothecopsis, and Phaeocalicium typically consist of elongated cells (Tibell, 1984, 1999).

When mature, most calicioids have open apothecial disks covered by a layer of ascospores forming a true mazaedium. The spore mass sticks together remarkably well and can in some species protrude as a column easily two or three times longer than the width of the capitulum. A true mazaedium is defined to consist of both ascospores and sterile elements, which together form a powdery but cohesive mass. The ascospores are released "passively" through disintegrating ascus walls and continue to mature in the mazaedium. This feature (prototunicate ascus) is unusual among Ascomycota and has evolved independently in several different lineages from ancestors with apical dehiscence apparatus (Wedin and Tibell, 1997; Wedin et al., 2000; Prieto et al., 2013).

The mazaedium is black in Calicium (Plate II, 1 and 2) and medium to dark brown in Chaenotheca (Plate II, 3 and 4), with the color being largely determined by the surface color of mature ascospores. The ascospores of most Chaenotheca species are nonseptate and essentially spherical, while those of Calicium are one-septate. The often very rough surface ornamentation of ascospores, together with sclerotized paraphyses and refuse matter, helps to keep the spore mass intact, and some force is typically needed to remove spores from the mazaedium.

The ascospores of Chaenothecopsis, Phaeocalicium, and other Mycocaliciales are discharged through the ascus apex and do not form a true mazaedium (Plate II, 5 and 6). However, some species in these genera effectively accumulate a layer of ascospores on their apothecial surfaces. In such fungi, the paraphysis tips can form a more or less solid epithecium and the ascospores discharged are released through pores in this structure. Often the released ascospores stick together due to amorphous substances (Schmidt, 1970; Tibell, 1984; Rikkinen, 2003c; Tuovila, 2013).

Ascomata of many Calicium and Chaenotheca lichens have crystallized secondary metabolites forming a distinct ring along the excipulum margin and sometimes also covering the lower side of the capitulum (Plates II, 1,3 and III, 1,2). Especially on young ascomata, the pruina can also extend to the stalk, and in some species, the stalk remains distinctly pruinose even when mature. The pruina can consist of various substances including anthraquinones or vulpinic acid, and some Calicium and Chaenotheca species also accumulate the same or related compounds in their thalli (Plate II, 1,3). The characteristic ring of pruina might simply reflect high metabolic activity in the maturing capitulum and the resulting discharge of waste products on the excipulum 
surface. However, the conspicuous accumulation of specific metabolites in highly specific locations does not really support this simple explanation. Vulpinic acid and anthraquinones have antimicrobial and antiherbivore qualities and they might thus give protection against grazing invertebrates (Asplund and Wardle, 2013; Nguyen et al., 2013; Gaya et al., 2015). Still, even more likely is that these hydrophobic substances help to keep the mazaedium dry. A hydrophobic pruina on the excipulum edge effectively helps to remove all water droplets from the mazaedial surface, which itself is distinctly hydrophobic. This function promotes mazaedial integrity and thus is consistent with the spore-saving strategy of calicioid mazaedia (Rikkinen, 1995).

Most calicioid lichens have ascospores with strongly thickened and darkly pigmented walls. The melanin pigments in the spore wall protect ascospores in the mazaedium from ultraviolet radiation, this again being constituent with the spore-saving strategy. The typical spore wall ornamentation of different genera is achieved via different ontogenetic processes as summarized in Tibell (1984). In Chaenotheca, the primary wall of the ascospore increases in thickness and its outer surface is finally ruptured by irregular cracks. The resulting ornamentation ranges from weak to very coarse in some species. In Calicium a secondary wall is deposited beneath the primary wall. The secondary wall increases in thickness and finally forms the bulk of the spore wall, with the ruptured primary wall forming the surface ornamentation. The spore walls of most Chaenothecopsis and Phaeocalicium species are not very strongly thickened. The spore wall is typically pale or lightly pigmented, and any surface ornamentation, if present, is formed by internal irregularities in the outer layer of the spore wall (Tibell, 1975, 1980, 1984).

The mycobionts of calicioid lichens establish symbiotic associations with green algae (Raths, 1938; Tschermak- Woess, 1978a; Tibell, 1984, 1999). The diversity of photobionts is high but as yet poorly known. For example, different species of Chaenotheca are known to associate with species of Symbiochloris Skaloud, Friedl, A. Beck et Dal Grande, Trebouxia Puymaly or Stichococcus Nägeli (Microthamniales), or Trentepohlia Martius (Trentepohliales). Each fungal species is believed to usually associate with only one photobiont genus, but levels of specificity have as yet hardly been studied with modern methods (Tibell, 2001; Tibell and Beck, 2002; LópezBautista et al., 2006; Hodac et al., 2016; Skaloud et al., 2016).

Several calicioid fungi produce coelomycetous and/or hypomycetous conidial states in culture, and in some cases such anamorphs can even be recognized in the field. The ecological role of the anamorphs is poorly understood, but they may function in reproduction or dispersal or both. They might play a role in the establishment of biotic associations in lichen-symbiotic and parasitic species, and it is possible that some species can survive as saprotrophes or commensals before entering into more specific relationships with optimal photobionts or hosts (Bonar, 1971; Vobis, 1980; Hawksworth, 1981; Samuels and Buchanan, 1983; Honegger, 1985; Tibell, 1990, 1991b, 1993, 1997; Tibell and Constantinescu, 1991; Beimforde et al., 2017b).

\subsection{Distribution}

The vast majority of extant calicioids live in forests, share similar habitat requirements, and can form characteristic communities in specific types of microhabitats (e.g., Tibell, 1999; Titov, 2006; Rikkinen, 2003a; Selva, 2013). For example, epiphyte communities rich in calicioid species are remarkably similar in composition 
over the entire circumpolar belt of boreal coniferous forests and adjoining areas of temperate coniferousdeciduous forests (Tibell, 1975, 1980, 1999; Peterson and Rikkinen, 2003; Titov, 2000, 2001, 2006; Rikkinen, 2003a; Selva, 2010, 2013, 2014). A number of calicioid species have bipolar distributions and thus also occur in temperate forests of the southern hemisphere (Tibell, 1987, 1994, 1998). Some species extend their range into subtropical and tropical regions, where they typically occur at high altitudes and occupy zones corresponding to their latitudinal range (Tibell, 1981b, 1982, 1984, 1996a, 2006; Sparrius et al., 2002; Tibell and Thor, 2003; Thor et al., 2008; Tibell and Frisch, 2010). In addition to widely distributed taxa, many regional endemics also exist (Tibell, 1994; Titov, 2006). One problem presently hindering the accurate evaluation of calicioid distributions is that the species delimitations of very few widely distributed taxa have as yet been studied with the use of DNA methods (Tibell, 2001, 2002, 2006; Vinuesa et al., 2001; Tibell and Beck, 2002; Tibell and Vinuesa, 2005; Yahr, 2015).

The macroclimatic optima of many boreal and temperate calicioids seem to be in subcontinental regions, and a number of widely distributed Chaenotheca species, for example, are rare in the most oceanic sections of northwestern Europe and western North America (Tibell, 1980; Middelborg and Mattsson, 1987; Rikkinen, 2003a). This may more reflect the lack of suitable substrate than the climate per se. In temperate rainforests, the calicioids, which depend on hard lignum, can be in short supply of suitable substrate as dead tree trunks tend to decompose rapidly and the lignum formed is soft and very rapidly overgrown by bryophytes. Also, mollusk grazing can be a major threat. This may explain why many lignicolous calicioids are most commonly found in slightly continental and indifferent sections of the boreal zone and in corresponding altitudinal belts in mountain regions of the temperate zone.

\subsection{Ecology}

Despite their wide ranges, individual calicioid species often occur only in rather restricted and specialized microhabitats. Most species grow on either bark or hard lignum and are found on basal tree trunks in temperate and boreal forests (Middelborg and Mattsson, 1987; Tibell, 1992; Selva, 1994, 2003, 2013, 2014; Rikkinen, 1995, 2003a; Holien, 1996, 1998; Titov, 1998, 2000, 2001; Titov et al., 2004; McMullin and Arsenault, 2016). Others are substrate specialists that only grow on resinous exudates of conifers (Bonar, 1971; Titov and Tibell, 1993, 1999; Rikkinen, 1999, 2003c,d; Tuovila et al., 2013, 2014; Rikkinen et al., 2014, 2016; Selva and Tuovila, 2016) or angiosperms (Tibell and Titov, 1995; Selva and Tibell, 1999; Tuovila et al., 2011a, 2014; Tuovila, 2013; Beimforde et al., 2017b), on thalli of calicioid or other lichens (Hawksworth, 1978; Löfgren and Tibell, 1979; Tibell and Ryman, 1995; Titov, 2006), on basiomata of polyporoid fungi (Hawksworth, 1980; Tibell, 1981a; Hutchison, 1987; Muñiz et al., 2013; Hawksworth et al., 2014; Allen and McMullin, 2015; Suija et al., 2015), on leafy liverworts (Øvstedal and Vevle, 1967; Döbbeler and Feuerer, 2004), and even on bark or thin twigs of woody plants (Tibell, 1991a, 1996b; Kalb and Hafellner, 1992; Titov, 1994; Peterson and Rikkinen, 1998; Berglund et al., 2004). The range of nutritional ecologies is concurrently wide as the group includes both lichensymbiotic, parasitic and saprotrophic species (Tschermak- Woess, 1978b, 1980; Lücking et al., 2017). 
While saprotrophic and parasitic calicioids are obviously restricted to their particular hosts, the substrate requirements of calicioid lichens are somewhat wider. Many bark-inhabiting species grow on the basal trunks of conifers or deciduous trees, especially old and slow-growing trunks. They frequently grow on the rough edges of bark fissures, but under favorable conditions, they also extend onto smooth bark and can sometimes cover large surfaces. With respect to substrate chemistry, most species are clearly acidiphytic and anitrophytic, which gives them an advantage in competition for space against some rapidly growing macrolichens. Species-specific differences in substrate preferences are seen as clear difference in calicioid community composition between different tree species (Räsänen, 1927; Koskinen, 1955; Halonen, 1990; Halonen et al., 1991; Hyvärinen et al., 1992; Rikkinen, 2003a; Bäcklund et al., 2016; Hardman et al., 2017).

Some calicioids only grow on standing hard lignum, which represents a characteristic and often abundant substrate type in many natural boreal and temperate forests (Lõhmus and Lõhmus, 2001; Niemelä et al., 2002; Nascimbene et al., 2008; Spribille et al., 2008; Svensson et al., 2016; Santaniello et al., 2017). Calicioids can grow on either bark or lignum or both, and the degree of preference varies between different taxa. Some species that regularly grow on hard old lignum can also colonize old log buildings, fence posts, and other worked wood (Areskoug and Thor, 2005; Svensson et al., 2005; Petersen et al., 2017). Patches of exposed lignum on scarred trees provide enough substrate for numerous lignum-inhabiting calicioids, and even the deep scars left by woodpeckers can offer an ideal microhabitat for some species (Plate IV, 1). The basiomata of polypores represent yet another unusual substrate and microhabitat type exploited by some specialized calicioids (Hawksworth et al., 2014; Allen and McMullin, 2015; Suija et al., 2015).

The microclimatic conditions prevailing within a forest stand, which are often closely correlated with successional age, are more important determinants of calicioid species richness than any single macroclimatic parameter (Tibell, 1992; Selva, 1994, 2003; Rikkinen, 1995, 2003a; Lõhmus and Lõhmus, 2011; Dymytrova et al., 2016). A number of calicioid species are restricted to mature and old-growth forests, these being rich in appropriate substrates and having a favorable forest microclimate. Some calicioid species, among other epiphytic lichens, have been successfully used as indicators for identifying forest stands with long habitat continuity and subsequently high conservation value (Tibell, 1992; Kuusinen and Siitonen, 1998; Selva, 2002, 2003; Ranius et al., 2008). However, the specific reasons for the old-growth dependence can vary between different forest types and regions (McMullin et al., 2008; Berglund et al., 2009; Nascimbene et al., 2010; Lõhmus and Lõhmus, 2011; Lõhmus et al., 2007, 2012; Marmor et al., 2013; Lättman et al., 2014; Selva, 2016) and between different groups of lichen epiphytes (Johansson, 2008; Rheault et al., 2009; Hauck, 2011; Ellis, 2012; Hauck et al., 2013; Nascimbene et al., 2013).

While not all reasons for the old-growth dependence calicioids are necessarily known, both substrate factors and high air humidity are clearly important for explaining the habitat preferences of many old-growth associated species; in addition, light conditions are important for lichensymbiotic species. Some calicioids grow only in deeply shaded microhabitats that are also well protected from rain but promote a high and constant atmospheric humidity. For example, some Chaenotheca species grow in deep trunk crevices and root overhangs that are dimly lit and well protected from rain. Such species also occur on humus in rock crevices and caves, especially under north-facing cliff overhangs, again in microhabitats that retain high atmospheric humidity throughout the year. 
Barkman (1958) noted that some calicioid lichens were found only from the northern edges of forests bordering marshes, bogs, and riparian habitats and at the southwestern edges of forest glades, where they typically grew on the northeastern sides of mature tree trunks. Also, James et al. (1977) noted that these species mainly grew on the northeastern sides of deciduous trees. As explained in detail by Rikkinen (1995), the calicioid lichens that grow on northfacing surfaces of tree trunks at the northern edges of woods bordering forest glades very frequently experience "open shade" conditions. The remarkably cool microclimate of such sites is caused by the radiation conditions that regularly develop in the close vicinity of open vertical north-facing surfaces where there is a constant outgoing flux of long-wave radiation to the open sky and only diffuse radiation from the northern sky can compensate for the heat loss. The surface temperatures of epiphytic lichens in such open shade habitats often remain considerably below air temperature, while the lichens still receive considerable amounts of diffuse light, which is relatively rich in blue wavelengths. In suitable environments of the boreal and temperate zones, the open shade effect can be experienced at any time of the year, but such conditions are only rarely experienced in oceanic regions with cloudy and foggy climates. During the winter, the open shade effect is more pronounced and, because of the low elevations of the sun, more extended as well. It is especially characteristic for areas where areas of low vegetation occur among taller canopies. Also, small forest glades are typical open shade environments and often remain relatively cool and moist for most of the day.

During the winter season, open shade conditions are experienced in a range of sites that would be characterized as deeply shaded in the summer. Light reflection from snow may be very important for calicioid lichens at such sites, on the condition that they can photosynthesize at low temperatures. Many calicioid lichens grow on the basal trunks of trees, on slanting tree trunks, and on the undersides of overhanging logs and branches. In these microhabitats, light intensity is typically low in the summer but can be high at times in late winter and early spring due to intense light reflection from snow. Such calicioid-rich microhabitats can thus be described as distinctly cheimophotophytic. There is evidence that both symbionts of some boreal and temperate calicioid lichens are able to grow under low temperatures and that the photobionts of some temperate and tropical species may be relatively susceptible to frost (Tschermak-Woess, 1984, 1989; Nash et al., 1987; Tibell, 1991b; Rikkinen, 1995, 2003a; Marini et al., 2011).

As a whole, there is ample evidence that many boreal and temperate calicioid lichens benefit from open shade conditions. This influences their habitat selection and distribution on many spatial scales. On individual tree trunks, they prefer expositions where open shade conditions are most likely to occur. Also, within individual forests, they show a preference for similar locations and thus directly benefit from the structurally variability of old-growth stands, which offer a wide range of microhabitats that combine favorable light conditions with high atmospheric humidity. On wider geographical scales, calicioid communities tend to be most diverse and abundant in regions where macroclimate favors the development of open shade conditions (Rikkinen, 1995, 2003a). Forest-inhabiting calicioids suffer from major disturbances, such as forest fires, but clearly benefit from small and medium scale disturbances, such as isolated treefalls and limited insect outbreaks. Moderate disturbances can promote calicioid diversity both by increasing substrate availability for lignum-dependent species and by improving light conditions within the lower canopy, without still jeopardizing the humid forest microclimate. Differences in disturbance history are likely to explain many patterns in calicioid diversity both on 
the landscape level and even between adjacent forest stands (Rikkinen, 1995, 2003a; Lõhmus et al., 2007, 2012; Lõhmus and Lõhmus, 2011; Vehkaoja et al., 2017).

Tibell (1994) found that calicioid species with wide distributions have significantly smaller ascospores than do those with more restricted distributions. The obvious explanation would be that long-range dispersal by wind is more likely for species with small spores. While wind undoubtedly plays a central role in the dispersal of many calicioid species, there is growing evidence that dispersal by wood-inhabiting insects and other animals may be more important for others. Invertebrates crawling over calicioid ascomata can easily act as vectors that transport the ascospores directly into new habitats (Plate III, 3). Many woodboring insects have similar habitat requirements to those of calicioid species and can easily come into contact with the staining mazaedia. Some such insects are strong fliers and can transport ascospores over long distances directly into specific new microhabitats. Also, woodpeckers and other birds and even some mammals are likely to promote the dispersal of some calicioid species (Rikkinen, 1995, 2003a; Tuovila et al., 2011b; Messuti et al., 2012; Rikkinen et al., 2016; Beimforde et al., 2017a).

\section{FOSSIL CALICIOIDS PRESERVED IN AMBER}

Many extant resinicolous species regularly colonize semisolid resin and produce their ascomata on hardened resin or resin-impregnated wood and bark (Plate IV). Also, some calicioid lichens frequently grow in or around resinproducing cankers and sometimes produce ascomata on hardened resin (Plate V). Because their ascomata are tiny, they are easily engulfed by subsequent flows of fresh exudate and are then fossilized if the resin turns into amber (Plates V, VI, VII, and VIII). Due to all these characteristics, the overall prospects for finding fossil calicioids in amber are good.

Indeed, no fewer than six specimens of resinicolous Chaenothecopsis have been found from Baltic and Bitterfeld ambers (Rikkinen and Poinar, 2000; Tuovila et al., 2013; Rikkinen et al., 2018). Also, three specimens of Calicium, five fossil specimens of Chaenotheca, and one specimen of Phaeocalicium have so far been found (Rikkinen, 2003b; Kaasalainen et al., 2017; Kettunen et al., 2018; Rikkinen et al., 2018). Some of these fossils have since been used as minimum age constraints for dating phylogenies of Ascomycota (Prieto and Wedin, 2013, 2017; Beimforde et al., 2014).

The first fossil of Chaenothecopsis was found from Bitterfeld amber and described as Chaenothecopsis bitterfeldensis by Rikkinen and Poinar (2000). The ascomata of the type specimen represent different developmental stagesfrom small initials to mature ascomata, some with a well developed spore mass on top of the capitulum. The preservation of ascospores is excellent, and as some of the spores had germinated before preservation, they reveal different stages of development from germ tube formation to hyphal elongation. The ascomata arise from a superficial hyphal mat, but also the original resin substrate is infested with hyphae, often with irregularly thickened hyphal walls and spirally twisted regions (Plate VI).

In its overall morphology and anatomical details, Chaenothecopsis bitterfeldensis closely resembles some extant resinicolous species of the genus. Apart from being slightly larger, the ascospores of the fossil are identical to extant taxa of Chaenothecopsis Group D (Tuovila et al., 2014). While there is some variation in the size and 
shape of ascomata in the five other Chaenothecopsis fossils found from European amber, also all of them are very similar to $C$. bitterfeldensis and to each other, and most probably all represent the same lineage. The full range of morphological variation revealed by the six fossils is comparable to that of extant species, and scanning electron micrscopic images of fragmented ascospores isolated from two of the fossils demonstrate that even ultrastructural details of spores are identical to those of extant species (Rikkinen et al., 2018).

The first fossil of a calicioid lichen from Baltic amber was described by Robert Caspary in 1886 as Stilbum succini and recently transferred to the genus Calicium in Kettunen et al. (2018). The ascospores of this fossil are similar to those of another Calicium specimen recently found from Bitterfeld amber, which also revealed many details in ascospore ultrastructure (Rikkinen et al., 2018). The preserved features of the two fossils correspond with those of extant species in Calicium Clade A (Prieto and Wedin, 2017). A third Calcium specimen from Baltic amber does not belong to the same clade but cannot be safely assigned to any one extant group because species of two extant lineages produce comparable ascomata and similar ascospores (Rikkinen et al., 2018).

In addition, four of the five Chaenotheca fossils from European amber are very similar to their extant relatives. The first fossil specimen (Plate VII, 1) was reported by Rikkinen (2003b) as Chaenotheca sp. and the others were described in Rikkinen et al. (2018) and found to represent one or possibly two additional species. However, many extant Chaenotheca species are notoriously plastic and their accurate identification requires examination of ascus and photobiont characteristics that cannot be seen in the fossils. Furthermore, as intrageneric relationships within Chaenotheca have not yet been comprehensively analyzed with DNA methods, the Chaenotheca fossils cannot as yet been assigned to specific lineages within their genus (Rikkinen et al., 2018).

The fifth Chaenotheca fossil (Plate VII, 3) deviates from all extant species in important anatomical details and was described as a fossil species, Chaenotheca succina Rikkinen et A.R. Schmidt, in Rikkinen et al. (2018). The three features that characterize the fossil species (intertwining hyphae of stipe surface, persisting paraphyses of mazaedium, continuous outer layer of ascospore wall) may represent ancestral features that have not been preserved in modern species of the genus.

The overall morphology of the two ascomata preserved in the single Phaeocalicium fossil is similar to those of extant species of the genus but does not reveal details of ascospore morphology (Rikkinen et al., 2018).

The calicioid fossils demonstrate that key features in the morphology of Calicium, Chaenotheca, Chaenothecopsis, and Phaeocalicium ascomata have remained unchanged at least since the Paleogene. One Chaenotheca fossil differs from extant species in some anatomical details, but these differences do not change the general observation that all four genera have very conservatively maintained key morphological features that are relevant for their sporesaving strategy and the long-term maintenance of specialized niches in their forest habitat.

One prime example of maintenance of ecologically important adaptations is given by the branching and proliferating ascomata of several Chaenothecopsis fossils (Tuovila et al., 2013; Rikkinen et al., 2018). The ascomata of several extant species in the genus occasionally produce apothecial disks divided into distinct regions or lobes. Some species can also produce branched ascomata, and this feature is especially common among resinicolous taxa with long and slender stipes. In some species, the branching occurs close to the tip of the stipe, with each short branch forming a separate apothecial disk. This type of branching can lead to compound capitula, in some cases with up to a dozen partially contiguous apothecial disks (Rikkinen, 2003c). 
The stipes of some resinicolous Chaenothecopsis species branch low and hence tend to have long branches, and the ascomata of others form multilayered groups via branching and proliferation directly through the hymenium. This morphology, which is also preserved in two amber fossils, is restricted to resinicolous species that often live on cankers and wounds that exude resin over extended periods. The unusual morphology is a specific adaptation to growing near active resin flows: the perennial fungi can continue growth after commonly reoccurring incidents where their ascomata are overrun and partially covered by fresh exudate (Tuovila et al., 2013).

Mycocalicium sequoiae Bonar, an extant resinicolous calicioid that, despite its current name, belongs to the same lineage as some resinicolous Chaenothecopsis species (Tuovila et al., 2014), only grows on exudate that issues from the exposed heartwood of living specimens of Sequoiadendron giganteum (Lindl.) J. Buchholz and Sequoia sempervirens Endl. in western North America (Bonar, 1971; Tibell and Titov, 1995; Rikkinen, 2003a). This relationship is likely to date back to at least the Paleogene, when both host genera were more widely distributed on the Northern Hemisphere. Also, the close relationship of resinicolous Chaenothecopsis fossils from European Paleogene amber to extant taxa from East Asia and eastern and western North America suggests that the current distribution of these fungi is strongly relictual. The current European distribution, with a main population in the boreal forests of northern Europe and some small populations in the montane forests of central and Mediterranean Europe, indicates that they survived the last glacial maximum together with Picea A. Dietr. and Abies Mill. Taking into consideration what is now known of their past and present distribution, one can safely assume that the resinicolous species were more widespread in Europe during the early and middle Weichselian, when Picea abies (L.) H. Karst. was widely distributed and common in central and southeastern Europe (Tuovila et al., 2011b, 2013).

\section{DISCUSSION}

Baltic amber forms the largest amber deposit on Earth, and assumptions about the locality, geographic extent, structure, and floral composition of its source forests have been a matter of debate since the launch of the intensive study of Baltic amber inclusions in the 19th century. The assumptions about the source forests of Baltic amber have generally been based on the ecological interpretations of inclusions of plants and animals (Sadowski et al., 2017). While Conwentz (1890) assumed dense humid and warm pine forests with only a few deciduous trees, other authors of the 19th century distinguished the source area into lowlands with subtropical to warmtemperate plant taxa and mountains in which taxa having extant analogous in the northern high latitudes occurred (Göppert, 1853; Caspary, 1872; Göppert, 1883). These authors saw affinities to extant floras of northern America, East Asia, and Europe.

Ander (1942) interpreted the presence of various climatic indicator taxa of plants and animals as being a result of the vertical stratification of the forest into different altitudinal zones and described the "Baltic amber forest" as a warm-temperate, moist, and dense "jungle" mainly composed of conifer trees. In Ander's opinion (1942), the climate was predominantly humid, warm-temperate, and only locally subtropical. A similar picture of 
the "Baltic amber forest" was suggested by Bachofen-Echt (1949), who emphasized the different climatic implications of taxa from the Baltic amber flora and fauna.

Czeczott (1961) provided a compilation of described Baltic amber plants and highlighted the high proportion of presumed tropical and subtropical plant taxa (23\% of the total number of species) in the Baltic amber flora and agreed with the suggestions of a moist and dense amber forest. She further suggested the presence of open forest glades.

Schubert $(1953,1961)$ and Rüffle and Helms (1970) proposed drier conditions for the Baltic amber source area and suggested similarities to the "hammocks" of Florida and the mountain steppe forests of Cuba. They assumed that the "Baltic amber forest" was generally dominated by pines and palms, that hard-leaved woods occurred along rivers, and that the higher mountains were covered by pine-oak forests. Kohlman-Adamska (2001) suggested such pine-oak steppe forests in the foothills, supposed the presence of humid swamps along the rivers in lower elevations and suggested that pure conifer forests were located in higher altitudes. She concluded that the spatially structured topography of the area as well as the location of the "Baltic amber forest" in the transition of the temperate to subtropical zone led to a high diversity of the flora.

Other recent publications (Weitschat, 1997; Wichard et al., 2009; Weitschat and Wichard, 2010) regard the "Baltic amber forest" as tropical, combined with mountainous subtropical rain forests, a notion that is mainly based on the interpretation of arthropod inclusions. In contrast, coleopteran inclusions from Baltic amber studied by Alekseev and Alekseev (2016) hint of a plain landscape with a thermophilic, humid-mixed climax forest community.

The East European Craton is a prime example of longterm geologic stability (Nikishin et al., 1996), and no orogenetic events occurred in the Baltic region before or during the Paleogene. Hence, there is no geological evidence for the presence of any mountains of any height in the Baltic amber source area, which makes any perception of mountain taxa obsolete.

Sadowski et al. (2017) evaluated previously described and recently found inclusions of conifers from Baltic amber taxonomically and paleoecologically and used these fossils along with ecological data from their closest fossil and extant analogues to reconstruct habitats and climate of the source area of the Baltic amber. The findings indicate heterogeneous warm-temperate humid forest types and point to a "horizontal" stratification of the Baltic amber source area into various habitat types, comprising coastal lowland swamps, back swamps, riparian forests, mesophytic mixed conifer-angiosperm forests, and meadows. Lichen assemblages from Baltic and Bitterfeld ambers suggest that the climate of European Paleogene amber forests was relatively humid and most likely temperate. The morphological adaptations observed in the fossil lichens are most consistent with a humid and moderately wellilluminated temperate forest (Kaasalainen et al., 2017).

As demonstrated by our present analysis, the conspicuously prominent presence of calicioid lichens and fungi among the amber inclusions provides strong support to the emerging perception of European Paleogene amber forests as structurally variable mosaics of dense and more open forest stands. There is full reason to believe that the calicioid lichens preserved in amber preferred similar open shade habitats as their modern relatives (Plate IX). On individual trees, they mainly grew on trunk surfaces that regularly experienced open shade conditions. Also within the forest landscape, they preferred structurally variable old-growth stands, which offered abundant lignum, bark and resin substrates, and a plethora of microhabitats that combined favorable 
light conditions with high atmospheric humidity (Plate IX). On the basis of what is known about the substrate preferences and overall ecological requirements of extant calicioids, we propose a likely microhabitat of each fossil and by combining all these data produce an idealized model of forest stand where all these fossils could even have lived side by side. This model may represent the best presently available proxy for European Paleogene amber forest structure (Plate X).

\section{ACKNOWLEDGMENTS}

This study would not have been possible without the generous support of amber enthusiasts who detected amber inclusions of calicioid fungi and lichens in their collections and made them available for research. We especially thank Volker Arnold (Heide), Heinrich Grabenhorst (Wienhausen), Carsten Gröhn (Glinde), Max Kobbert (Münster), George O. Poinar, Jr. (Corvallis), and Jörg Wunderlich (Hirschberg an der Bergstraße) for providing amber specimens with inclusions of calicioids. Bruce McCune and Patricia Muir (Corvallis) kindly supported our field work in Oregon. Stella Kristin Louise Meinke (Göttingen) imaged the specimens illustrated in Plate II, 1, 3, and 5 .

\section{REFERENCES}

Alekseev, V.I., and P.I. Alekseev. 2016. New approaches for reconstruction of the ecosystem of an Eocene amber forest. Biology Bulletin 43: 75-86.

Allen, J.L., and R.T. McMullin. 2015. Chaenotheca balsamconensis, a new calicioid lichen on Trichaptum abietinum from North America that is benefiting from widespread conifer fatalities. The Bryologist 118: 54-58.

Ander, K. 1942. Die Insektenfauna des Baltischen Bernsteins nebst damit verknüpften zoogeographischen Problemen. Lunds Universitets Årsskrift 38: 1-82.

Areskoug, V., and G. Thor. 2005. Distribution, status and ecology of the lichen Cyphelium notarisii in Sweden. Annales Botanici Fennici 42: 317-326.

Asplund, J., and D.A. Wardle. 2013. The impact of secondary compounds and functional characteristics on lichen palatability and decomposition. Journal of Ecology 101: 689-700.

Bachofen-Echt, A. 1949. Der Bernstein und seine Einschlüsse. Springer, Wien. 204 pp.

Bäcklund, S., M. Jönsson, J. Strengbom, A. Frisch, and G. Thor. 2016. A pine is a pine and a spruce is a spruce - The effect of tree species and stand age on epiphytic lichen communities. PLoS ONE 11(1): e0147004.

Barkman, J.J. 1958. Phytosociology and ecology of cryptogamic epiphytes. Van Gorcum, Assen, The Netherlands. 628 pp.

Beimforde, C., and A.R. Schmidt. 2011. Microbes in resinous habitats: a compilation from modern and fossil resins. Lecture Notes in Earth Sciences 131: 391-407.

Beimforde, C., K. Feldberg, S. Nylinder, J. Rikkinen, H. Tuovila, H. Dörfelt, M. Gube, D. Jackson, J. Reitner, L.J., Seyfullah, and A.R. Schmidt. 2014. Estimating the Phanerozoic history of the Ascomycota lineages: combining fossil and molecular data. Molecular Phylogenetics and Evolution 78: 386-398.

Beimforde, C., L.J. Seyfullah, V. Perrichot, G. Kuschel, K. Schmidt, J. Rikkinen, and A.R. Schmidt. 2017a. Resin exudation and resinicolous communities on Araucaria humboldtensis in New Caledonia. Arthropod-Plant Interactions 11: 495-505.

Beimforde, C., H. Tuovila, M. Gube, W.G. Lee, A.R. Schmidt, and J. Rikkinen. 2017b. Chaenothecopsis schefflerae (Ascomycota, Mycocaliciales): a widespread fungus on semi-hardened exudates of endemic New Zealand Araliaceae. New Zealand Journal of Botany 11: 1-20.

Berglund, H., R.B. O'Hara, and B.G. Jonsson. 2009. Quantifying habitat requirements of tree-living species in fragmented boreal forests with bayesian methods. Conservation Biology 23: 1127-1137. 
Berglund, T, J. Hermansson, F. Jonsson, and G. Thor. 2004. New records of Phaeocalicium in Scandinavia. Symbolae Botanicae Upsalienses 34: 49-52.

Blumenstengel, H. 2004. Zur Palynologie und Stratigraphie der Bitterfelder Bernsteinvorkommen (Tertiär). Exkursionsführer und Veröffentlichungen der Deutschen Gesellschaft für Geowissenschaften 224: 17.

Bonar, L. 1971. A new Mycocalicium on scarred Sequoia in California. Madronõ 21: 62-69.

Bruch, A.A., and V. Mosbrugger. 2002. Palaeoclimate versus vegetation reconstruction palynological investigations on the Oligocene sequence of the Sava Basin, Slovenia. Review of Palaeobotany and Palynology 122: 117-141.

Caspary, R. 1872. Privatsitzung am 4. October. Schriften der Königlichen physikalisch-ökonomischen Gesellschaft zu Königsberg 13: 15-19.

Caspary, R. 1886. Einige neue Pflanzenreste aus dem Samländischen Bernstein. Schriften der physikalischökonomischen Gesellschaft zu Königsberg, 27, 1-8.

Clauer, N., J. Huggett, and S. Hillier. 2005. How reliable is the K-Ar glauconite chronometer? A case study of Eocene sediments from the Isle of Wight. Clay Minerals 40: 167-176.

Conwentz, H. 1890. Monographie der baltischen Bernsteinbäume: vergleichende Untersuchungen über die Vegetationsorgane und Blüten, sowie über das Harz und die Krankheiten der baltischen Bernsteinbäume. Verlag Wilhelm Engelmann, Leipzig, Germany, $151 \mathrm{pp}$.

Czeczott, H. 1961. The flora of the Baltic amber and its age. Prace Muzeum Ziemi 4: 119-145.

Dal Corso, J., A.R. Schmidt, L.J. Seyfullah, N. Preto, E. Ragazzi, H.C. Jenkyns, X. Delclòs, D. Néraudeau, and G. Roghi. 2017. Evaluating the use of amber in palaeoatmospheric reconstructions: The carbon-isotope variability of modern and Cretaceous conifer resins. Geochimica et Cosmochimica Acta 199: 351-369.

Döbbeler, P., and T. Feuerer. 2004. Stenocybe nitida (Mycocaliciales), an unusual ascomycete on Plagiochila punctata. Bibliotheca Lichenologica 88: 91-102.

Dunlop, J.A. 2010. Bitterfeld amber. In D. Penney (ed.), Biodiversity of Fossils in Amber from the Major World Deposits, pp. 57-68. Siri Scientific Press, Manchester, UK.

Dymytrova, L., S. Stofer, C. Ginzler, F.T. Breiner, and C. Scheidegger. 2016. Forest-structure data improve distribution models of threatened habitat specialists: Implications for conservation of epiphytic lichens in forest landscapes. Biological Conservation 196: 31-38.

Ellis, C.J. 2012. Lichen epiphyte diversity: A species, community and trait-based review. Perspectives in Plant Ecology, Evolution and Systematics 14: 131-152.

Ferguson, D.K., M. Pingen, R. Zetter, and C.-C. Hofmann. 1998. Advances in our knowledge of the Miocene plant assemblage from Kreuzau, Germany. Review of Palaeobotany and Palynology 101: 147-177.

Gaya, E., S. Fernández-Brime, R. Vargas, R.F. Lachlan, C. Gueidan, M. Ramírez-Mejía, and F. Lutzoni. 2015. The adaptive radiation of lichen-forming Teloschistaceae is associated with sunscreening pigments and a bark-to-rock substrate shift. Proceedings of the National Academy of Sciences, USA 112: 11600-11605.

Göppert, H.R. 1853. Über die Bernsteinflora. Bericht über die zur Bekanntmachung geeigneten Verhandlungen der Königlich Preußischen Akademie der Wissenschaften zu Berlin 1853: 450-477.

Göppert, H.R. 1883. Von den Bernstein-Coniferen, insbesondere auch in ihren Beziehungen zu den Coniferen der Gegenwart. In H. R. Göppert, and A. Menge (eds), Die Flora des Bernsteins und ihre Beziehung zur Flora der Tertiärformation und der Gegenwart, pp. 1-63. Verlag Wilhelm Engelmann, Leipzig, Germany.

Grimaldi, D., and A. Ross. 2017. Extraordinary Lagerstätten in amber, with particular reference to the Cretaceous of Burma. In N.C. Fraser, and H.-D Sues (Eds), Terrestrial Conservation Lagerstätten: Windows into the Evolution of Life on Land, pp. 287-342. Dunedin Academic Press Ltd, Edinburgh, UK.

Halonen, P. 1990. Some interesting notes on the Caliciales of central Finland. Graphis Scripta 3: 28-31.

Halonen, P., M. Hyvärinen, and M. Kauppi. 1991. The epiphytic lichen flora on conifers in relation to climate in the Finnish middle boreal zone. The Lichenologist 23: 61-72.

Hardman, A., D. Stone, and S. Selva. 2017. Calicioid lichens and fungi of the Gifford Pinchot and Okanogan-Wenatchee National Forests in Washington, U.S.A. Opuscula Philolichenum 16: 1-14.

Hartl, C., A.R. Schmidt, J. Heinrichs, L.J. Seyfullah, N. Schäfer, C. Gröhn, J. Rikkinen, and U. Kaasalainen. 2015. Lichen preservation in amber: morphology, ultrastructure, chemofossils, and taphonomic alteration. Fossil Record 18: 127-135.

Hauck, M. 2011. Site factors controlling epiphytic lichen abundance in northern coniferous forests. Flora 206: 8190.

Hauck, M., U. de Bruyn, and C. Leuschner. 2013. Dramatic diversity losses in epiphytic lichens in temperate broadleaved forests during the last 150 years. Biological Conservation 157: 136-145.

Hawksworth, D.L. 1978. Notes on British lichenicolous fungi: II. Notes from the Royal Botanic Garden, Edinburgh. 36: 181-197. 
Hawksworth, D.L. 1980. Two little-known members of the Mycocaliciaceae on polypores. Transactions of the British Mycological Society 74: 650-651.

Hawksworth, D.L. 1981. The lichenicolous Coleomycetes. Bulletin of the British Museum (Natural History). Botany 9: 1-98.

Hawksworth, D.L., B. Aguirre-Hudson, and A.M. Ainsworth. 2014. Sphinctrina tigillaris, an overlooked species of Chaenothecopsis growing on Perenniporia meridionalis, a polypore new to the UK. The Lichenologist 46: 729735.

Hibbett, D.S., M. Binder, J.F. Bischoff, M. Blackwell, P.F. Cannon, O.E. Eriksson, S.Huhndorf, T. James, P.M. Kirk, R. Lücking, H.T. Lumbsch, F. Lutzoni, P.B. Matheny, D.J. McLaughlin, M.J. Powell, S. Redhead, C.L. Schoch, J.W. Spatafora, J.A. Stalpers, R. Vilgalys, M.C. Aime, A. Aptroot, R. Bauer, D. Begerow, G.L. Benny, L.A. Castlebury, P.W. Crous, Y.-C. Dai, W. Gams, D.M. Geiser, G.W. Griffith, C. Gueidan, D.L. Hawksworth, G. Hestmark, K. Hosaka, R.A. Humber, K. D Hyde, J.E. Ironside, U. Kõljalg, C.P. Kurtzman, K.-H. Larsson, R. Lichtwardt, J. Longcore, J. Miądlikowska, A. Miller, J.-M. Moncalvo, S. Mozley-Standridge, F. Oberwinkler, E. Parmasto, V. Reeb, J.D. Rogers, C. Roux, L. Ryvarden, J.P. Sampaio, A. Schüßler, J. Sugiyama, R.G. Thorn, L. Tibell, W.A. Untereiner, C. Walker, Z. Wang, A. Weir, M. Weiss, M.M .White, K. Winka, Y.-J. Yao, and N. Zhang. 2007. A higher-level phylogenetic classification of the Fungi. Mycological Research 111: 509-547.

Hodač, L., C. Hallmann, K. Spitzer, J. Elster, F. Faßhauer, N. Brinkmann, D. Lepka, V. Diwan, and T. Friedl. 2016. Widespread green algae Chlorella and Stichococcus exhibit polar-temperate and tropical-temperate biogeography. FEMS Microbial Ecology 92.

Holien, H. 1996. Influence of site and stand factors on the distribution of crustose lichens of the caliciales in a suboceanic spruce forest area in central Norway. The Lichenologist 28: 315-330.

Holien, H. 1998. Lichens in spruce forest stands of different successional stages in central Norway with emphasis on diversity and old growth species. Nova Hedwigia 66: 283-324.

Honegger, R. 1985. The hyphomycetous anamorph of Coniocybe furfuracea. The Lichenologist 17: $273-279$.

Hutchison, L.J. 1987. Studies on Phaeocalicium polyporaeum in North America. Mycologia 79: 786-789.

Hyvärinen, M., P. Halonen, and M. Kauppi. 1992 Influence of stand age and structure on the epiphytic lichen vegetation in the middle-boreal forests of Finland. The Lichenologist 24: 165-180.

James, P.W., D.L. Hawksworth, and F. Rose. 1977. Lichen communities in the British Isles: a preliminary conspectus. In M.R.D. Seaward MRD (Ed.), Lichen Ecology, pp. 295-413. Academic Press, London, UK.

Johansson, P. 2008. Consequences of disturbance on epiphytic lichens in boreal and near boreal forests. Biological Conservation 141: 1933-1944.

Kaasalainen, U., J. Heinrichs, M. Krings, L. Myllys, H. Grabenhorst, J. Rikkinen, and A.R. Schmidt. 2015 Alectorioid morphologies in Paleogene lichens: New evidence and re-evaluation of the fossil Alectoria succini Mägdefrau. PLOS ONE 10(6): e0129526.

Kaasalainen, U., A.R. Schmidt, and J. Rikkinen. 2017. Diversity and ecological adaptations in Paleogene lichens. Nature Plants 3, 17049: 1-8.

Kalb, K., and J. Hafellner. 1992. Bemerkenswerte Flechten und lichenicole Pilze von der Insel Madeira. Herzogia 9: 45102.

Kasiński, J.R., and R. Kramarska 2008. Sedimentary environment of amber-bearing association along the Polish-Russian Baltic coastline. Exkursionsführer und Veröffentlichungen der Deutschen Gesellschaft für Geowissenschaften 236: 46-57.

Kettunen, E., H. Grabenhorst, C. Gröhn, H. Dörfelt, J. Rikkinen, and A.R. Schmidt. 2015. The enigmatic hyphomycete Torula sensu Caspary revisited. Review of Palaeobotany and Palynology 219: 183-193.

Kettunen, E., A.R. Schmidt, P. Diederich, H. Grabenhorst, and J. Rikkinen. 2016. Lichen-associated fungi from Paleogene amber. New Phytologist 209: 896-898.

Kettunen, E., E-M. Sadowski, L.J. Seyfullah, H. Dörfelt, J. Rikkinen, and A.R. Schmidt. 2018. Caspary's fungi from Baltic amber: historic specimens and new evidence. (submitted to Palaeontology November, 2017).

Knuth, G., T. Koch, I. Rappsilber, and L. Volland. 2002. Concerning amber in the Bitterfeld region - geologic and genetic aspects. Hallesches Jahrbuch für Geowissenschaften 24: 35-46.

Kohlman-Adamska, A. 2001. A graphic reconstruction of an 'amber' forest. In B. Kosmowska-Ceranowicz (ed.), The Amber Treasure Trove - The Tadeusz Giecewicz's Collection at the Museum of the Earth, Polish Academy of Sciences, pp. 15-18. Oficyna Wysawnicza Sadyba, Warsaw, Poland.

Koskinen, A. 1955. Über die Kryptogamen der Bäume, besonders die Flechten, im Gewässergebiet des Päijanne sowie an den Flussen Kalajoki, Lestijoki und Pyhäjoki. Floristische, soziologische und ökologische Studie I. Mercatorin Kirjapaino, Helsinki, Finland. 176 pp.

Kosmowska-Ceranowicz, B., and N. Vávra. 2015. Infrared spectra of the world's resins. Holotype characteristics. Museum of the Earth, Warsaw, Poland. $280 \mathrm{pp}$. 
Kosmowska-Ceranowicz, B., A. Kohlman-Adamska, and I. Grabowska. 1997. Erste Ergebnisse zur Lithologie und Palynologie der bernsteinführenden Sedimente im Tagebau Primorskoje. Metalla 66: 5-17.

Kunzmann, L., and H. Walther. 2012. Early Oligocene plant taphocoenoses of the Haselbach megafloral complex and the reconstruction of palaeovegetation. Palaeobiodiversity and Palaeoenvironments 92: 295-307.

Kuusinen, M., and J. Siitonen. 1998. Epiphytic lichen diversity in old-growth and managed Picea abies stands in southern Finland. Journal of Vegetation Science 9: 283-292.

Labandeira, C. 2014. Amber. In M. Laflamme, J.D. Schiffbauer, and S.A.F. Darroch (Eds), Reading and Writing of the Fossil record: Preservational Pathways to Exceptional Fossilization. The Paleontological Society Papers 20: 164216.

Langenheim, J. H. 2003. Plant resins - Chemistry, Evolution, Ecology, and Ethnobotany. Timber Press, Portland, OR. 586 pp.

Liehmann, G. 2013. Die maschinelle Gewinnung und Aufbereitung des Bernsteins im Tagebau Goitsche bei Bitterfeld ein Erlebnisbericht. Exkursionsführer und Veröffentlichungen der Deutschen Gesellschaft für Geowissenschaften 249: 24-30.

López-Bautista, J.M., F. Rindi, and M.D. Guiry. 2006. Molecular systematics of the subaerial green algal order Trentepohliales: an assessment based on morphological and molecular data. International Journal of Systematic and Evolutionary Microbiology 56: 1709-1715.

Lücking, R., B.P. Hodkinson, and S.D. Leavitt. 2017. Corrections and amendments to the 2016 classification of lichenized fungi in the Ascomycota and Basidiomycota. The Bryologist 120: 58-69.

Lättman, H., K-O. Bergman, M. Rapp, M. Tälle, L. Westerberg, and P. Milberg. 2014. Decline in lichen biodiversity on oak trunks due to urbanization. Nordic Journal of Botany 32: 518-528.

Löfgren, O., and L. Tibell. 1979. Sphinctrina in Europe. The Lichenologist 11: 109-137.

Lõhmus, P., and A. Lõhmus. 2001 Snags, and their lichen flora in old Estonian peatland forests. Annales Botanici Fennici 38: 265-280.

Lõhmus, A., and P. Lõhmus. 2011. Old-forest species: The importance of specific substrata vs. stand continuity in the case of calicioid fungi. Silva Fennica 45: 1015-1039.

Lõhmus, A., P. Lõhmus, and K. Vellak. 2007. Substratum diversity explains landscape-scale co-variation in the species-richness of bryophytes and lichens. Biological Conservation 135: 405-414.

Lõhmus, P., E. Leppik, J. Motiejunaite, A. Suija, and A. Lõhmus. 2012. Old selectively cut forests can host rich lichen communities. Nova Hedwigia 95: 493-515.

Marini, L., J. Nascimbene, and P.L. Nimis. 2011. Large-scale patterns of epiphytic lichen species richness: Photobiont-dependent response to climate and forest structure. Science of the Total Environment 409 : 4381-4386.

Marmor, L., T. Tõrra, L. Saag, E. Leppik, and T. Randlane. 2013. Lichens on Picea abies and Pinus sylvestris. The Lichenologist 45: 51-63.

Martínez-Delclòs, X., D. E. Briggs, and E. Peñalver. 2004. Taphonomy of insects in carbonates and amber. Palaeogeography, Palaeoclimatology, Palaeoecology 203: 19-64.

McMullin, R.T., and A. Arsenault. 2016. The calicioids of Newfoundland, Canada. Opuscula Philolichenum 15: 92-104.

McMullin, R.T., P.N. Duinker, R.P. Cameron, D.H.S. Richardson, and I.M. Brodo. 2008. Lichens of coniferous old growth forests of southwestern Nova Scotia, Canada: Diversity and present status. The Bryologist 111: 620637.

Messuti, M.I., R. Vidal-Russell, G.C. Amico, and L.E. Lorenzo. 2012. Chaenothecopsis quintralis, a new species of calicioid fungus. Mycologia 104: 1222-1228.

Middelborg, J., and J. Mattsson. 1987. Crustaceous lichenized species of the Caliciales in Norway. Sommerfeltia 5: 171.

Muñiz, D., E. Llop, and N.L. Hladun. 2013. Sphinctrina paramerae, a new Mediterranean lichenicolous species with non-septate spores. The Lichenologist 45: 137-143.

Nascimbene, J., L. Marini, L. Motta, R. Motta, and P.L. Nimis. 2008. Lichen diversity of coarse woody habitats in a Pinus-Larix stand in the Italian Alps. The Lichenologist 40: 153-163.

Nascimbene, J., L. Marini, and P.L. Nimis. 2010. Epiphytic lichen diversity in old-growth and managed Picea abies stands in alpine spruce forests. Forest Ecology and Management 260: 603-609.

Nascimbene, J., G. Thor, and P.L. Nimis 2013. Effects of forest management on epiphytic lichens in temperate deciduous forests of Europe - A review. Forest Ecology and Management 298: 27-38.

Nash, T.H. III, L. Kappen, R. Losch, D.W. Larson, and U. Matthes-Sears. 1987. Cold resistance of lichen with Trentepohlia- or Trebouxia-photobionts from the North American west-coast. Flora 179: 241-251.

Nguyen, K-H., M. Chollet-Krugler, N. Gouault, and S. Tomasi. 2013. UV-protectant metabolites from lichens and their symbiotic partners. Natural Product Reports 30: 1490-1508. 
Niemelä, T., T. Wallenius, and H. Kotiranta. 2002. The kelo tree, a vanishing substrate of specified woodinhabiting fungi. Polish Botanical Journal 47: 91-101.

Nikishin, A.M., P.A. Ziegler, R.A. Stephenson, S.A.P.L. Cloetingh, A.V. Furne, P.A. Fokin, A.V. Ershov, S.N. Bolotov, M.V. Korotaev, A.S. Alekseev, V.I. Gorbachev, E.V. Shipilov, A. Lankreijer, E.Y. Bembinova, and I.V. Shalimov. 1996. Late Precambrian to Triassic history of the East European Craton: dynamics of sedimentary basin evolution. Tectonophysics 268: 23-63.

$\varnothing$ vstedal, D.O., and O. Vevle. 1967. Funn av Stenocybe bryophyla W. Wats. i Norge. Blyttia 25: 124-125.

Penney, D. 2010. Biodiversity of Fossils in Amber from the Major World Deposits. Siri Scientific Press, Manchester, UK. 304 pp.

Petersen, K., L.M. Calabria, J.E.D. Miller, J. Brown-Clay, L. Hynson, T. Steen, K. Johnston, A. Ulbrich, E. Chandler, M. Miller, and J. Villella. 2017. Substrate age influences species richness and community composition of calicioid lichens and fungi on wooden buildings. The Bryologist 120: 19-24.

Peterson, E., and J. Rikkinen. 1998. Stenocybe fragmenta, a new species of Mycocaliciaceae with fragmenting spores. Mycologia 90: 1087-1090.

Peterson, E., and J. Rikkinen. 1999. Range extensions for selected pin-lichens and allied fungi in the Pacific Northwest. The Bryologist 102: 370-376.

Prieto, M., E. Baloch, A. Tehler, and M. Wedin. 2013. Mazaedium evolution in the Ascomycota (Fungi) and the classification of mazaediate groups of formerly unclear relationship. Cladistics 29: 296-308.

Prieto, M., and M. Wedin. 2013. Dating the diversification of the major lineages of Ascomycota (Fungi). PLOS ONE 8(6): e65576.

Prieto, M., and M. Wedin. 2017. Phylogeny, taxonomy and diversification events in the Caliciaceae. Fungal Diversity 82: 221-238.

Ragazzi, E. and A.R. Schmidt. 2011. Amber. In J. Reitner, and V. Thiel (Eds), Encyclopedia of Geobiology, pp. 24-36. Springer, Dordrecht, The Netherlands.

Ranius, T., P. Johansson, N. Berg, and M. Niklasson. 2008. The influence of tree age and microhabitat quality on the occurrence of crustose lichens associated with old oaks. Journal of Vegetation Science 19: 653-662.

Rappsilber, I. 2016. Fauna und Flora des Bitterfelder Bernsteinwaldes. Eine Auflistung der bis 2014 publizierten Organismentaxa aus dem Bitterfelder Bernstein. Ampyx-Verlag, Halle/Saale, Germany. 78 pp.

Räsänen, V. 1927. Über Flechtenstandorte und Flechtenvegetation im westlichen Nordfinnland. Annales Botanici Societatis Zoologicae-Botanicae Fennicae "Vanamo" 7: 1-202.

Raths, H. 1938. Experimentelle Untersuchungen mit Flechtengonidien aus der Familie der Caliciaceen. Berichte der Schweizerischen Botanischen Gesellschaft 48: 329-416.

Rheault, H., L. Bélanger, P. Grondin, R. Ouimet, C. Herbert, and C. Dussault. 2009. Stand composition and structure as indicators of epixylic diversity in old-growth boreal forests. Ecoscience 16: 183-196.

Rikkinen, J. 1995. What's behind the pretty colours? A study on the photobiology of lichens. Bryobrothera 4: 1-239.

Rikkinen, J. 1999. Two new species of resinicolous Chaenothecopsis (Mycocaliciaceae) from western North America. The Bryologist 102: 366-369.

Rikkinen, J. 2003a. Calicioid lichens and fungi in the forests and woodlands of western Oregon. Acta Botanica Fennica 175: 1-41.

Rikkinen, J. 2003b. Calicioid lichens from European Tertiary amber. Mycologia 95: 1032-1036.

Rikkinen, J. 2003c. Chaenothecopsis nigripunctata, a remarkable new species of resinicolous Mycocaliciaceae from western North America. Mycologia 95: 98-103.

Rikkinen, J. 2003d. New resinicolous ascomycetes from beaver scars in western North America. Annales Botanici Fennici 40: 443-450.

Rikkinen, J., and G.O. Poinar, Jr. 2000. A new species of resinicolous Chaenothecopsis (Mycocaliciaceae, Ascomycota) from 20 million year old Bitterfeld amber, with remarks on the biology of resinicolous fungi. Mycological Research 104: 7-15.

Rikkinen, J., H. Tuovila, C. Beimforde, L.J. Seyfullah, V. Perrichot, and A.R. Schmidt. 2014. Chaenothecopsis neocaledonica sp. nov.: The first resinicolous mycocalicioid fungus from an araucarian conifer. Phytotaxa 173: 49-60.

Rikkinen, J., C. Beimforde, L. Seyfullah, V. Perrichot, K. Schmidt, and A.R. Schmidt. 2016. Resinogalea humboldtensis gen. et sp. nov., a new resinicolous fungus from New Caledonia, placed in Bruceomycetaceae, a new family of Ascomycota. Annales Botanici Fennici 53: 205-215.

Rikkinen, J., S.K.L. Meinke, H. Grabenhorst, C. Gröhn, M. Kobbert, J. Wunderlich, and A.R. Schmidt. 2018. Amber fossils of calicioid lichens and fungi. (submitted to Fungal Diversity, November, 2017).

Ritzkowski, S. 1997. K-Ar Altersbestimmungen der bernsteinführenden Sedimente des Samlandes (Paläogen, Bezirk Kaliningrad). Metalla 66: 19-24. 
Rüffle, L., and J. Helms. 1970. Waldsteppe und Insektenwelt im Bernstein, Beispiele aus der Bernsteinsammlung des Paläontologischen Museums. Wissenschaftliche Zeitschrift der Humboldt-Universität zu Berlin, MathematischNaturwissenschaftliche Reihe 19: 243-249.

Sadowski, E.-M., A.R. Schmidt, L.J. Seyfullah, and L. Kunzmann. 2017. Conifers of the 'Baltic amber forest' and their palaeoecological significance. Stapfia 106: 1-73.

Samuels, G.J., and D.E. Buchanan. 1983. Ascomycetes of New Zealand. 5 Mycocalicium schefflerae sp. nov., its ascal ultrastructure and Phialophora anamorph. New Zealand Journal of Botany 21: 163-170.

Santaniello, F., L.B. Djupström, T. Ranius, J. Weslien, J. Rudolphi, and G. Thor. 2017. Large proportion of wood dependent lichens in boreal pine forest are confined to old hard wood. Biodiversity and Conservation: 26: 1295-1310.

Schubert, K. 1953. Mikroskopische Untersuchung pflanzlicher Einschlüsse des Bernsteins - 2.Teil: Rinden und Borken. Palaeontographica Abteilung B 93: 103-119.

Schubert, K. 1961. Neue Untersuchungen über Bau und Leben der Bernsteinkiefer (Pinus succinifera (Conwentz) emend.) - Ein Beitrag zur Paläohistologie der Pflanzen. Beihefte zum Geologischen Jahrbuch 45: 1-149.

Škaloud, P., T. Friedl, C. Hallmann, A. Beck, and F. Dal Grande. 2016. Taxonomic revision and species delimitation of coccoid green algae currently assigned to the genus Dictyochloropsis (Trebouxiophyceae, Chlorophyta). Journal of Phycology 52: 599-617.

Schmidt, A. 1970. Anatomisch-taxonomische Untersuchungen an europäischen Arten der Flechtenfamilie Caliciaceae. Mitteilungen aus dem Institut für allgemeine Botanik in Hamburg 13: 111-166.

Schmidt, A.R., C. Beimforde, L.J. Seyfullah, S.-E. Wege, H. Dörfelt, V. Girard, H. Grabenhorst, M. Gube, J. Heinrichs, A. Nel, P. Nel, V. Perrichot, J. Reitner, and J. Rikkinen. 2014. Amber fossils of sooty moulds. Review of Palaeobotany and Palynology 200: 53-64.

Selva, S.B. 1994. Lichen diversity and stand continuity in the northern hardwoods and spruce-fir forests of northern New England and western New Brunswick. The Bryologist 94: 424-428.

Selva, S.B. 2002. Indicator species - restricted taxa approach in coniferous and hardwood forests of northeastern America. In P.L. Nimis, C. Scheidegger, and P.A. Wolseley PA (Eds), Monitoring with Lichens - Monitoring Lichens. Nato Science Series. IV. Earth and Environmental Sciences, pp. 349-352. Kluwer Academic Publishers, Dordrecht, The Netherlands.

Selva, S.B. 2003. Using calicioid lichens and fungi to assess ecological continuity in the Acadian Forest ecoregion of the Canadian Maritimes. The Forestry Chronicle 79: 550-558.

Selva, S.B. 2010. New and interesting calicioid lichens and fungi from eastern North America. The Bryologist 113: 272276.

Selva, S.B. 2013. The calicioid lichens and fungi of the Acadian Forest ecoregion of northeastern North America, I. New species and range extensions. The Bryologist 116: 248-256.

Selva, S.B. 2014. The calicioid lichens and fungi of the Acadian Forest ecoregion of northeastern North America, II. The rest of the story. The Bryologist 117: 336-367.

Selva, S.B. 2016. Calicioid lichens and fungi of Great Smoky Mountains National Park: Not a healthy population. Evansia 33: 106-122.

Selva, S.B., and L. Tibell. 1999. Lichenized and non-lichenized calicioid fungi from North America. The Bryologist 102: 377-397.

Selva, S.B., and H. Tuovila. 2016. Two new resinicolous mycocalicioid fungi from the Acadian Forest: One new to science, the other new to North America. The Bryologist 119: 417-422.

Seyfullah, L.J., and A.R. Schmidt. 2015. Stuck in time - life trapped in amber. Palaeontology Online, Volume 5, Article 12: 1-11.

Seyfullah, L.J., C. Beimforde, J. Dal Corso, V. Perrichot, V., J. Rikkinen, and A.R. Schmidt. 2018. Production and preservation of resins - past and present. Biological Reviews (in review).

Sparrius, L.B., A. Aptroot, and M-J. Lai. 2002. New reports of calicioid lichenized and non-lichenized ascomycetes from Taiwan. Mycotaxon 83: 357-360.

Spribille, T., G. Thor, F.L. Bunnell, T. Goward, and C.R. Björk. 2008. Lichens on dead wood: species-substrate relationships in the epiphytic lichen floras of the Pacific Northwest and Fennoscandia. Ecography 31: 741-750.

Standke, G. 1998. Die Tertiärprofile der Samländischen Bernsteinküste bei Rauschen. Schriftenreihe für Geowissenschaften 7: 93-133.

Standke, G. 2008. Bitterfelder Bernstein gleich Baltischer Bernstein? - Eine geologische Raum-Zeit-Betrachtung und genetische Schlußfolgerungen. Exkursionsführer und Veröffentlichungen der Deutschen Gesellschaft für Geowissenschaften 236: 11-33.

Suija, A., A. Suu, and P. Lõhmus. 2015. Substrate specificity corresponds to distinct phylogenetic lineages: The case of Chaenotheca brunneola. Herzogia 29: 355-363. 
Svensson, M., V. Johansson, A. Dahlberg, A. Frisch, G. Thor, and T. Ranius. 2016. The relative importance of stand and dead wood types for wood-dependent lichens in managed boreal forests. Fungal Ecology 20: 166-174.

Svensson, M., P. Johansson, and G. Thor. 2005. Lichens of wooden barns and Pinus sylvestris snags in Dalarna, Sweden. Annales Botanici Fennici 42: 351-363.

Thor, G., K.H. Moon, and L. Tibell. 2008. New findings of calicioid lichens and fungi in Korea. Journal of Japanese Botany 83: 256-258.

Tibell, L. 1975. The Caliciales of boreal North America. Taxonomy, ecological and distributional comparisons with Europe, and ultrastructural investigations in some species. Symbolae Botanicae Upsalienses 21: 1-128.

Tibell, L. 1980. The lichen genus Chaenotheca in the Northern Hemisphere. Symbolae Botanicae Upsalienses 23: 1-65.

Tibell, L. 1981a. Comments on Caliciales Exsiccatae II. The Lichenologist 13: 51-64.

Tibell, L. 1981b. Notes on Caliciales III. Some species from Africa. The Lichenologist 13: 161-165.

Tibell, L. 1982. Caliciales of Costa Rica. The Lichenologist 14: 219-254.

Tibell, L. 1984. A reappraisal of the taxonomy of Caliciales. Beihefte zur Nova Hedwigia 79: 597-713.

Tibell, L. 1987. Australasian Caliciales. Symbolae Botanicae Upsalienses 27: 1-279.

Tibell, L. 1990. Anamorphs in Mycocalicium albonigrum and M. subtile (Caliciales). Nordic Journal of Botany 10: 221242.

Tibell, L. 1991a. A new species of Stenocybe from Western North America. The Bryologist 94: 413-415.

Tibell, L. 1991b. The Asterophoma anamorph of Chaenothecopsis savonica and its hyphomycetous synanamorph. Can J Bot 69:2427-2433

Tibell, L. 1992. Crustose lichens as indicators of forest continuity in boreal coniferous forests. Nordic Journal of Botany 12: 427-450.

Tibell, L. 1993. The anamorphs of Chaenothecopsis viridireagens. Nordic Journal of Botany 13: 331-335.

Tibell, L. 1994. Distribution patterns and dispersal strategies of Caliciales. Botanical Journal of the Linnean Society 116 : 159-202.

Tibell, L. 1996a. Caliciales. Flora Neotropica Monograph 69: 1-78.

Tibell, L. 1996b. Phaeocalicium (Mycocaliciaceae, Ascomycetes) in northern Europe. Annales Botanici Fennici 33: 205221.

Tibell, L. 1997. Anamorphs in mazaediate lichenized fungi and the Mycocaliciaceae ("Caliciales s. lat"). Symbolae Botanicae Upsalienses 32: 291-322.

Tibell, L. 1998. Crustose mazaediate lichens and the Mycocaliciaceae in temperate South America. Bibliotheca Lichenologica 71: 1-107.

Tibell, L. 1999. Calicioid lichens and fungi. Nordic Lichen Flora 1: 20-94.

Tibell, L. 2001. Photobiont association and molecular phylogeny of the lichen genus Chaenotheca. The Bryologist 104: 191-198.

Tibell, L. 2002. Morphological variation and ITS phylogeny of Chaenotheca trichialis and C. xyloxena (Coniocybaceae, lichenized ascomycetes). Annales Botanici Fennici 39: 73-80.

Tibell, L. 2003. Tholurna dissimilis and generic delimitations in Caliciaceae inferred from nuclear ITS and LSU rDNA phylogenies (Lecanorales, lichenized ascomycetes). Mycological Research 107: 1403-1418.

Tibell, L. 2006. Calicium in the Indian Himalayas. Journal of the Hattori Botanical Laboratory 100: 809-851.

Tibell, L., and A. Beck. 2002. Morphological variation, photobiont association and ITS phylogeny of Chaenotheca phaeocephala and C. subroscida (Coniocybaceae, lichenized ascomycetes). Nordic Journal of Botany 21: 651660.

Tibell, L., and O. Constantinescu. 1991. Catenomycopsis rosea gen. et sp. nov. (Hyphomycetes), anamorph of Chaenothecopsis haematopus. Mycological Research 95: 556-560.

Tibell, L., and A. Frisch. 2010. New data on crustose mazaediate lichens from tropical Africa. Bibliotheca Lichenologica 104: 323-332.

Tibell, L., and K. Ryman. 1995. Revision of species of Chaenothecopsis with short stalks. Nova Hedwigia 602: $199-218$.

Tibell, L., and G. Thor. 2003. Calicioid lichens and fungi of Japan. Journal of the Hattori Botanical Laboratory 94: 205259.

Tibell, L., and A. Titov. 1995. Species of Chaenothecopsis and Mycocalicium (Caliciales) on exudate. The Bryologist 98 : 550-560.

Tibell, L., and M. Vinuesa. 2005. Chaenothecopsis in a molecular phylogeny based on nuclear rDNA ITS and LSU sequences. Taxon 54: 427-442.

Tibell, L., and M. Wedin. 2000. Mycocaliciales, a new order for nonlichenized calicioid fungi. Mycologia 92: 577-581.

Titov, A. 1994. A new Stenocybe species from Central Asia. Acta Botanica Fennica 150: 197-199

Titov, A. 1998. New and rare calicioid lichens and fungi from relict tertiary forests of Caucasus and the Crimea. Folia Cryptogamica Estonica 32: 127-133. 
Titov, A. 2000. Notes on calicioid lichens and fungi from the Gongga Mountains (Sichuan, China). The Lichenologist 32: 553-569.

Titov, A. 2001. Further notes on calicioid lichens and fungi from the Gongga Mountains (Sichuan, China). The Lichenologist 33: 303-314.

Titov, A. 2006. Mikokalizievye griby (porjadok Mycocaliciales) Golarktiki [Mycocalicioid fungi (the order Mycocaliciales) of Holarctic]. KMK Scientific Press, Moskva. $296 \mathrm{pp}$.

Titov, A., and L. Tibell. 1993. Chaenothecopsis in the Russian Far East. Nordic Journal of Botany 13: 313-329.

Titov, A., and L. Tibell. 1999. Chaenothecopsis tristis, a rare resinicolous species of the Mycocaliciaeae. Mycotaxon 70 : 471-476.

Titov, A., E.S. Kuznetsova, and D.E. Himelbrant 2004. Calicioid lichens and fungi from the Kamchatka Peninsula, Russia. Symbolae Botanicae Upsalienses 34: 455-464.

Tschermak-Woess, E. 1978a. Über die Phycobionten der Sektion Cystophora von Chaenotheca, insbesondere Dictyochloropsis splendida und Trebouxia simplex, spec. nova. Plant Systematics and Evolution 129: 185-208.

Tschermak-Woess, E. 1978b. Myrmecia reticulata as a phycobiont and free-living - free-living Trebouxia - the problem of Stenocybe septata. The Lichenologist 10: 69-79.

Tschermak-Woess, E. 1980. Chaenothecopsis consociata - kein parasitischer oder parasymbiontischer Piltz, sondern lichenisiert mit Dictyochloropsis symbiontica, spec. nova. Plant Systematics and Evolution 136: 287-306.

Tschermak-Woess, E. 1984. Über die weite Verbreitung lichenisierter Sippen von Dictyochloropsis und die systematische Stellung von Myrmecia reticulata (Chlorophyta). Plant Systematics and Evolution 147: $299-322$.

Tschermak-Woess, E. 1989. Developmental studies in trebouxioid algae and taxonomical consequences. Plant Systematics and Evolution 164: 161-195.

Tuovila, H. 2013. Sticky business - diversity and evolution of Mycocaliciales (Ascomycota) on plant exudates. Publications in Botany from the University of Helsinki 44: 1-23.

Tuovila, H., M.L. Davey, L-H. Yan, S. Huhtinen, and J. Rikkinen. 2014. New resinicolous mycocalicioid fungi from China. Mycologia 106: 989-1003.

Tuovila, H., J.R. Cobbinah, and J. Rikkinen. 2011. Chaenothecopsis khayensis, a new resinicolous calicioid fungus on African mahogany. Mycologia 103: 610-615.

Tuovila, H., P. Larsson, and J. Rikkinen. 2011. Three resinicolous North American species of Mycocaliciales in Europe with a re-evaluation of Chaenothecopsis oregana Rikkinen. Karstenia 51: 37-49.

Tuovila, H., A.R. Schmidt, C. Beimforde, H. Dörfelt, H. Grabenhorst, and J. Rikkinen. 2013. Stuck in time - a new Chaenothecopsis species with proliferating ascomata from Cunninghamia resin and its fossil ancestors in European amber. Fungal Diversity 58: 199-213.

van den Broeck, D., R. Lücking, E. Gaya, J.L. Chaves, J.B. Lejju, and D. Ertz. 2017. Heterocyphelium leucampyx (Arthoniales, Ascomycota): another orphaned mazaediate lichen finds its way home. The Lichenologist 49: 333345.

Vávra, N. 2008. Chemie des Baltischen und Bitterfelder Bernsteins: Methoden, Möglichkeiten, Resultate. Exkursionsführer und Veröffentlichungen der Deutschen Gesellschaft für Geowissenschaften 236: 69-76.

Vehkaoja, M., P. Nummi, and J. Rikkinen. 2017. Beavers promote calicioid diversity in boreal forest landscapes. Biodiversity and Conservation 26: 579-591.

Vinuesa, M., J. Sanches-Puelles, and L. Tibell. 2001. Intraspecific variation in Mycocalicium subtile (Mycocaliciaceae) elucidated by morphology and the sequences of the ITS1-5.8S-ITS2 region of rDNA. Mycological Research 105: 323-330.

Vobis, G. 1980. Bau und Entwicklung der Flechten-Pycnidien und ihrer Conidien. Bibliotheca Lichenologica 14: 1-141.

Wedin, M., and L. Tibell. 1997. Phylogeny and evolution of Caliciaceae, Mycocaliciaceae, and Sphinctrinaceae (Ascomycota), with notes on the evolution of the prototunicate ascus. Canadian Journal of Botany 75: 12361242.

Wedin, M, H. Döring, A. Nordin, and L. Tibell. 2000. Small subunit rDNA phylogeny shows the lichen families Caliciaceae and Physciaceae (Lecanorales, Ascomycotina) to form a monophyletic group. Canadian Journal of Botany 78: 246-254.

Wedin, M., E. Baloch, and M. Grube. 2002. Parsimony analyses of mtSSU and nITS rDNA sequences reveal the natural relationships of the lichen families Physciaceae and Caliciaceae. Taxon 51: 655-660.

Weitschat, W. 1997. Bitterfelder Bernstein - ein eozäner Bernstein auf miozäner Lagerstätte. Metalla 66: 71-84.

Weitschat, W., and W. Wichard. 2010. Baltic Amber. In D. Penney (Ed.), Biodiversity of Fossils in Amber from the Major World Deposits, pp. 80-115. Siri Scientific Press, Manchester, UK.

Wichard, W., C. Gröhn, and F. Seredszus. 2009. Aquatic Insects in Baltic Amber. Verlag Kessel, Remagen-Oberwinter, Germany. 336 pp. 
Wolfe, A.P., R. Tappert, K. Muehlenbachs, M. Boudreau, R.C. McKellar, J.F. Basinger, and A. Garrett. 2009. A new proposal concerning the botanical origin of Baltic amber. Proceedings of the Royal Society B 276: 3403-3412.

Wolfe, A.P., R.C. McKellar, R. Tappert, R.N.S. Sodhi, and K. Muehlenbachs 2016. Bitterfeld amber is not Baltic amber: Three geochemical tests and further constraints on the botanical affinities of succinate. Review of Palaeobotany and Palynology 225: 21-32.

Yahr, R. 2015. The status of the conservation priority species Calicium corynellum in the British Isles. The Lichenologist 47: 205-214.

Yamamoto, S., A. Otto, G. Krumbiegel, and B.R.T Simoneit. 2006. The natural product biomarkers in succinite, glessite and stantienite ambers from Bitterfeld, Germany. Review of Palaeobotany and Palynology 140: 27-49.
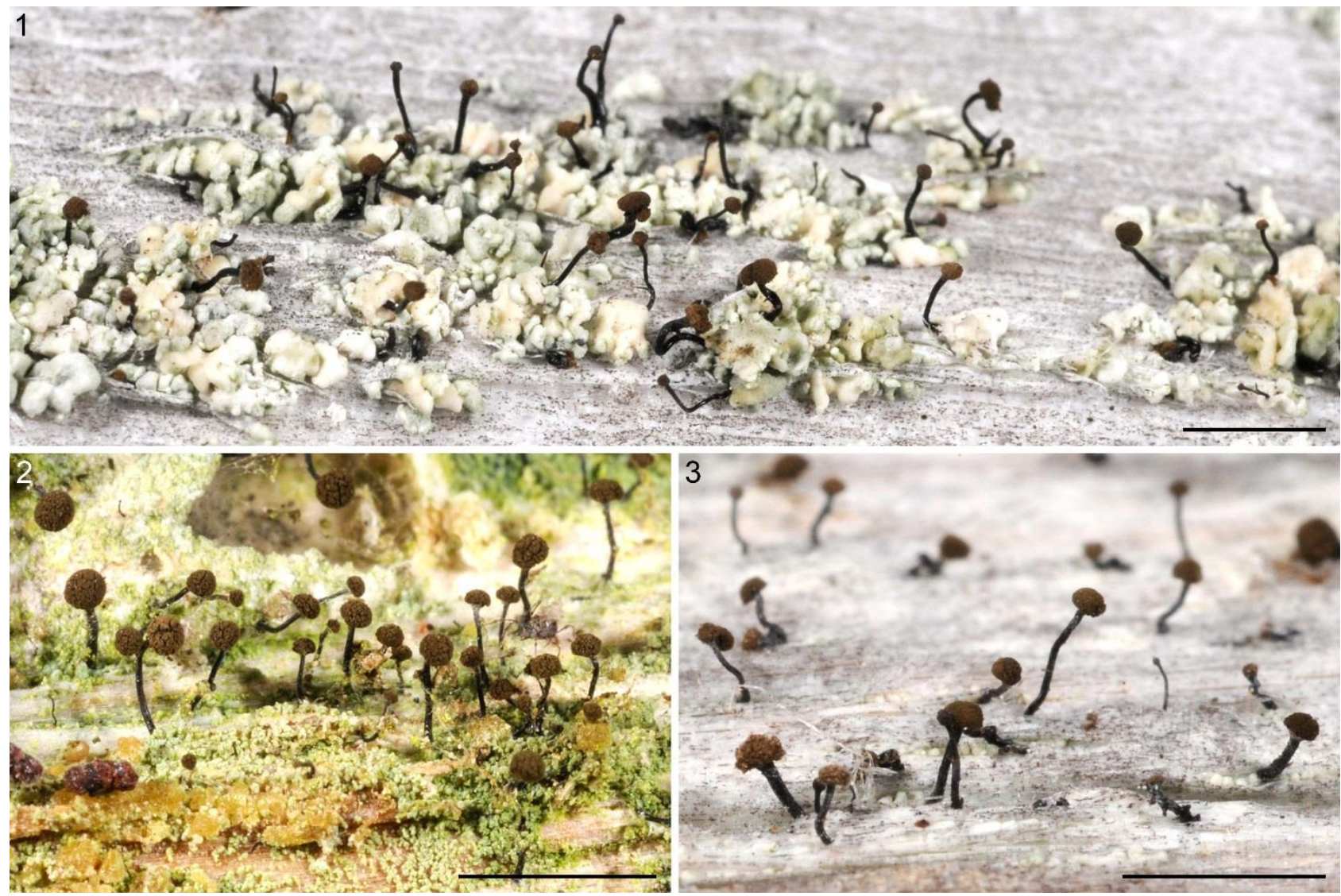

Plate I. Morphology of extant calicioid lichens of the genus Chaenotheca. 1. Chaenotheca trichialis (Ach.) Hellb. with minutely squamulose thallus. 2. Chaenotheca stemonea (Ach.) Müll. Arg. with farinaceous thallus. 3. Chaenotheca brunneola (Ach.) Müll. Arg. with immersed, endosubstratic thallus. All lichens were photographed in the field in central Finland. Scale bars $=2 \mathrm{~mm}$. 

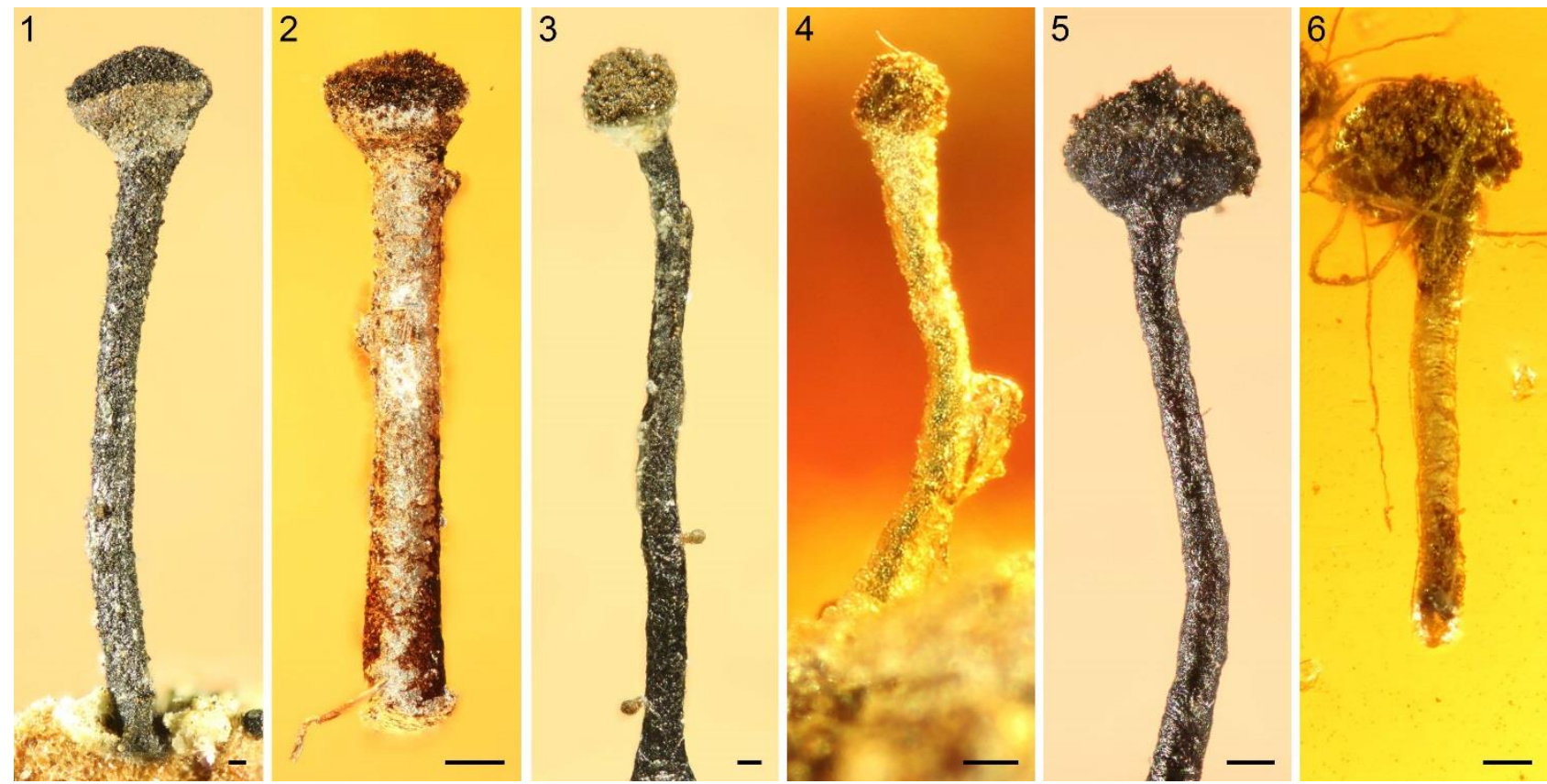

Plate II. Capitula and mazaedia of extant (1, 3, and 5) and fossil $(2,4$, and 6$)$ caliciods. The superficial similarity of ascoma morphology among phylogenetically distant fungi is a product of convergent evolution within calicioid communities towards a common spore-saving strategy and animal dispersal. 1. Calicium viride from Oregon. 2. Calicium sp. in Baltic amber (Geoscientific Collections of the University of Göttingen, GZG.BST.27296). 3. Chaenotheca brunneola from Oregon 4. Chaenotheca sp. in Bitterfeld amber (Heinrich Grabenhorst Amber Collection, Le-75). 5. Chaenothecopsis proliferatus Rikkinen, A.R. Schmidt et Tuovila from China. 6. Chaenothecopsis cf. bitterfeldensis in Bitterfeld amber (Heinrich Grabenhorst Amber Collection, Mi-55). Scale bars $=50 \mu \mathrm{m}$. 

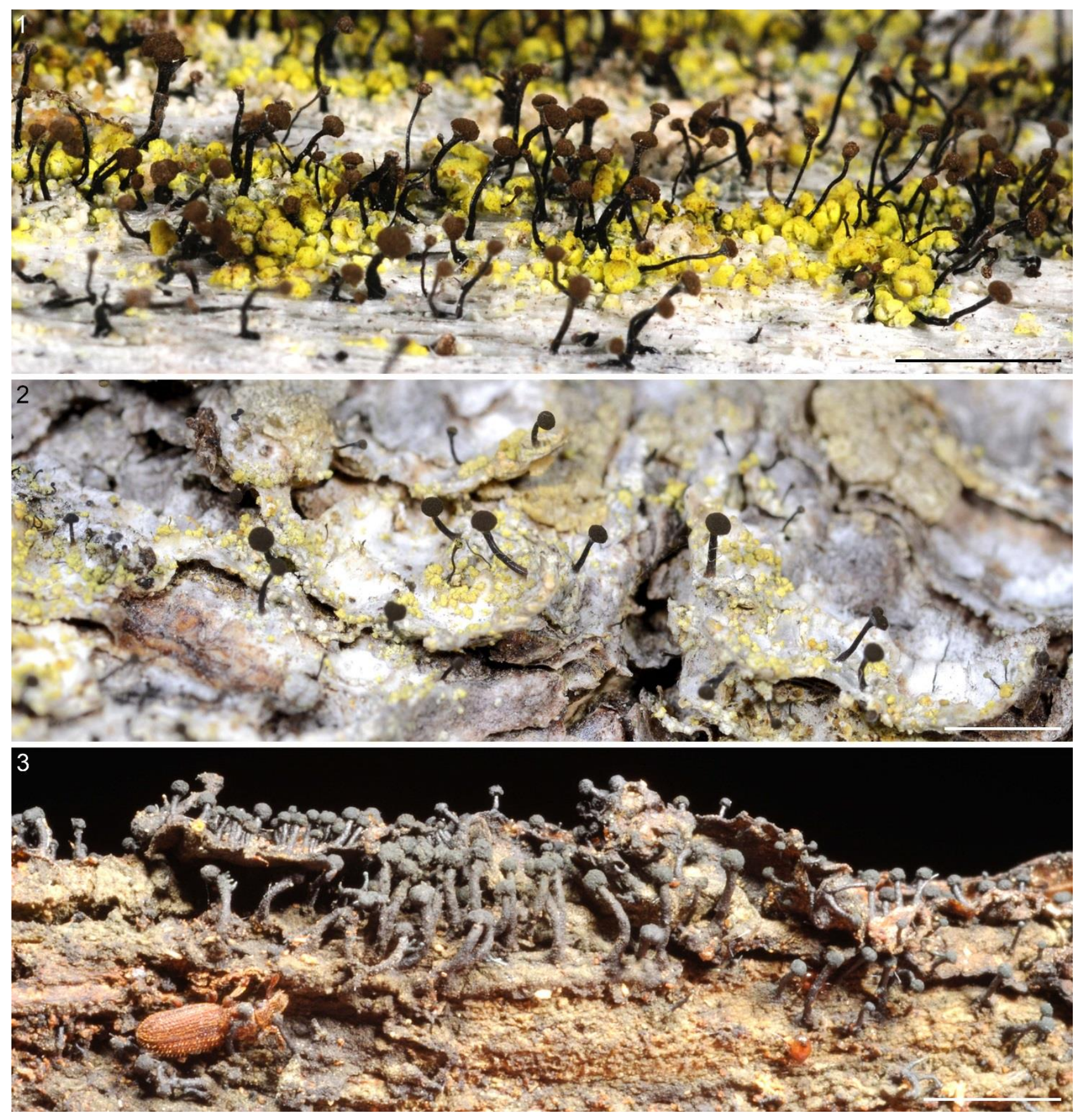

Plate III. Ecology of extant calicioid lichens and fungi. 1. Chaenotheca chrysocephala (Ach.) Th. Fr. has vulpinic acid and other yellow pulvinic acid derivatives in its thallus. In ascomata the same secondary metabolite accumulates to form a narrow ring along the excipulum margin and sometimes also covers the lower side of the capitulum. 2.

Chaenothecopsis consociata (Nádv.) A.F.W. Schmidt only grows on Chaenotheca chrysocephala and produces its large black ascomata on the thallus of its host. The Chaenotheca species suffers from the association as indicated by its pale color and limited production of host ascomata. 3. Chaenothecopsis schefflerae growing in a canker caused by woodboring insects on the stem of Pseudopanax colensoi K. Koch. Note small beetle seeking shelter between the ascomata (lower left) Invertebrates crawling over calicioid ascomata can transport the ascospores directly into new habitats. Also birds and even mammals promote the dispersal of some calicioid species. Chaenotheca chrysocephala and Chaenothecopsis consociata were photographed in central Finland and Chaenothecopsis schefflerae in New Zealand. Scale bars $=2 \mathrm{~mm}$. 

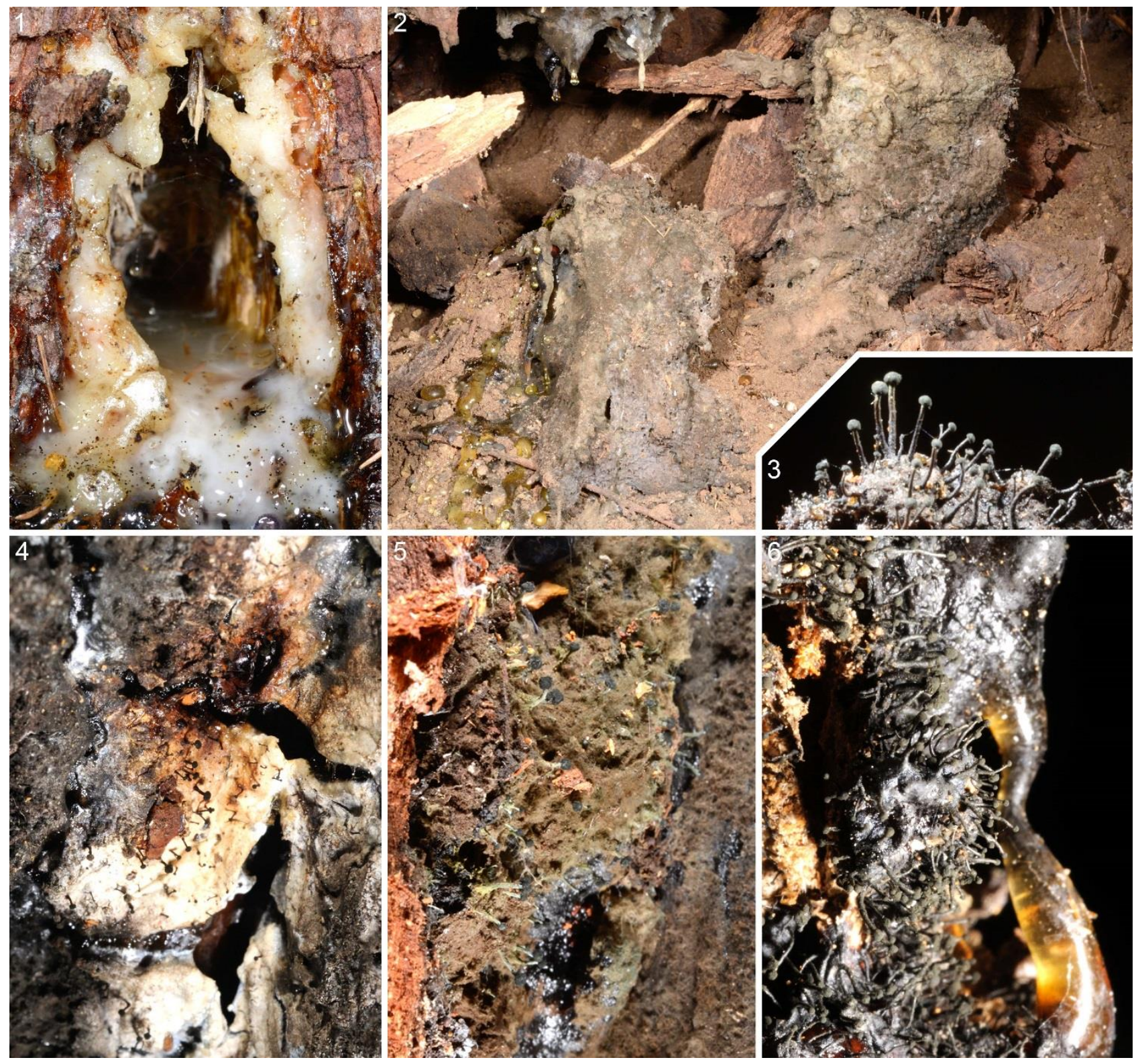

Plate IV. Ecology of extant resinicolous calicioids. 1. Resinous scars left by large woodpeckers can develop into ideal microhabitats for resinicolous Chaenothecopsis species. This deep scar on the basal trunk of Picea abies was produced by a black woodpecker (Dryocopus martius L.) in Finland. 2. Chaenothecopsis sitchensis Rikkinen grows on thick deposits of resin and organic debris that accumulate on soil within shady trunk base overhangs of huge old-growth Picea sitchensis in coastal forests of Oregon. 3. Chaenothecopsis sitchensis can produce much larger ascomata than most of its relatives, the longest stipe so far measured was $16 \mathrm{~mm}$ long. 4 . Three species of resinicolous Chaenothecopsis were found growing together in this canker on the basal trunk of Abies pinsapo Boiss. in southern Spain. 5. Chaenothecopsis tsugae Rikkinen and several other resinicolous species sometimes produce extensive hyphal mats especially behind bark slabs and in other sheltered microhabitats with high atmospheric humidity. This specimen was photographed in the Oregon Cascades. 6. Chaenothecopsis schefflerae (Samuels et D.E. Buchanan) Tibell grows on the exudates of several Pseudopanax species (Araliaceae) in New Zealand. 

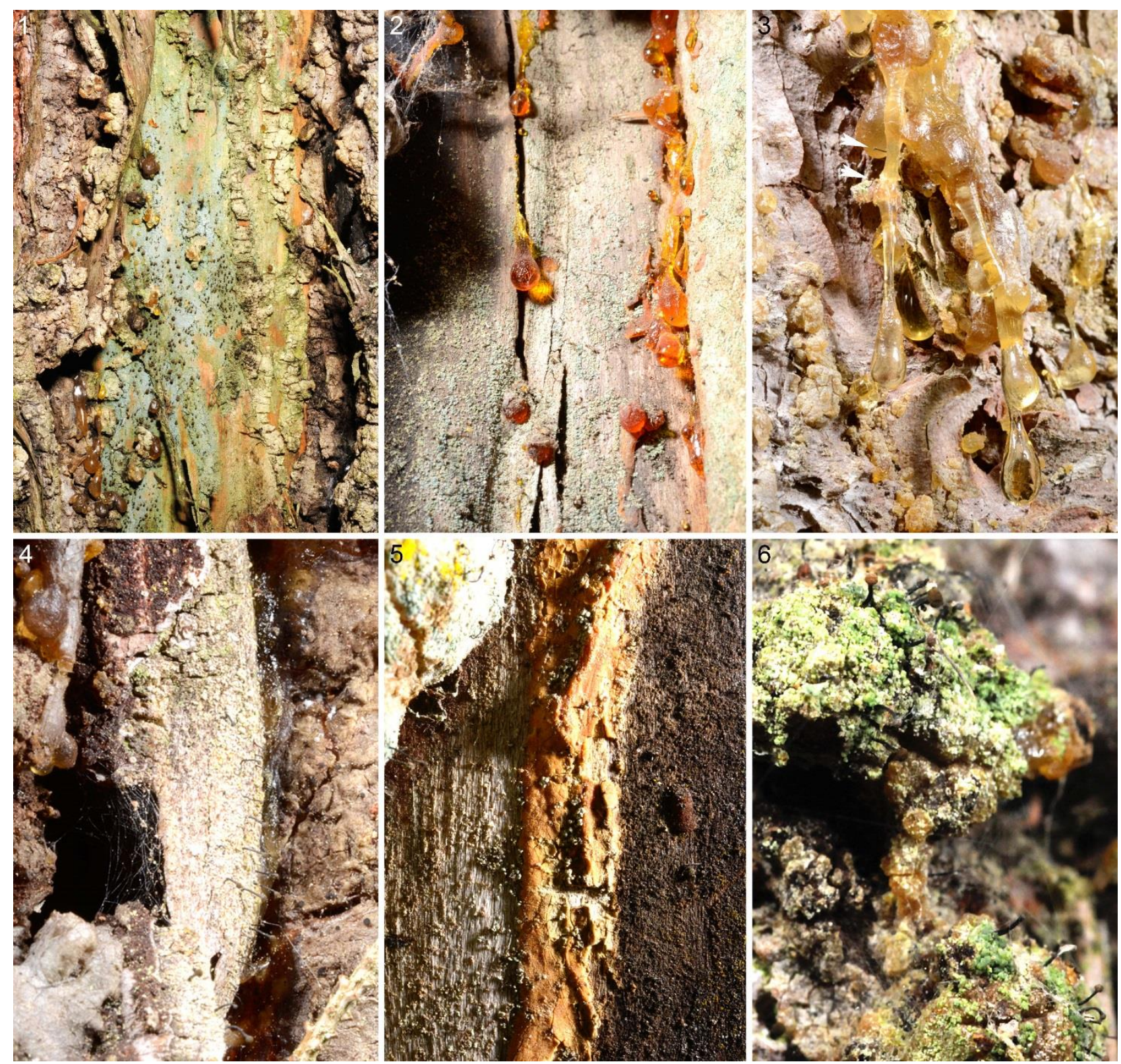

Plate V. Extant calicioid lichens and fungi in resinous microhabitats. 1. Patches of exposed lignum on scarred conifers provide an ideal habitat for many calicioid lichens and fungi. 2. Both resinicolous and lignum-inhabiting calicioids grow together in such habitats and can be easily engulfed by any subsequent flows of fresh exudate. 3 . Running resin can also engulf calicioids growing on conifer bark, note the two Chaenotheca ascomata that have only narrowly escaped this fate (arrowheads). 4. Ascomata of Chaenotheca ferruginea (Turner) Mig. growing immediately adjacent to active resin flow are under high risk of being covered by fresh exudate. 5. Chaenotheca trichialis (Ach.) Hellb. starting to colonize the surface of dry, hardened resin flow. 6. Chaenotheca trichialis producing ascomata on old and weathered resin flow. Images 1, 3 and 6 were photographed on Picea abies in central Finland and images 2, 4 and 5 of Sequoia sempervirens in northern California. 

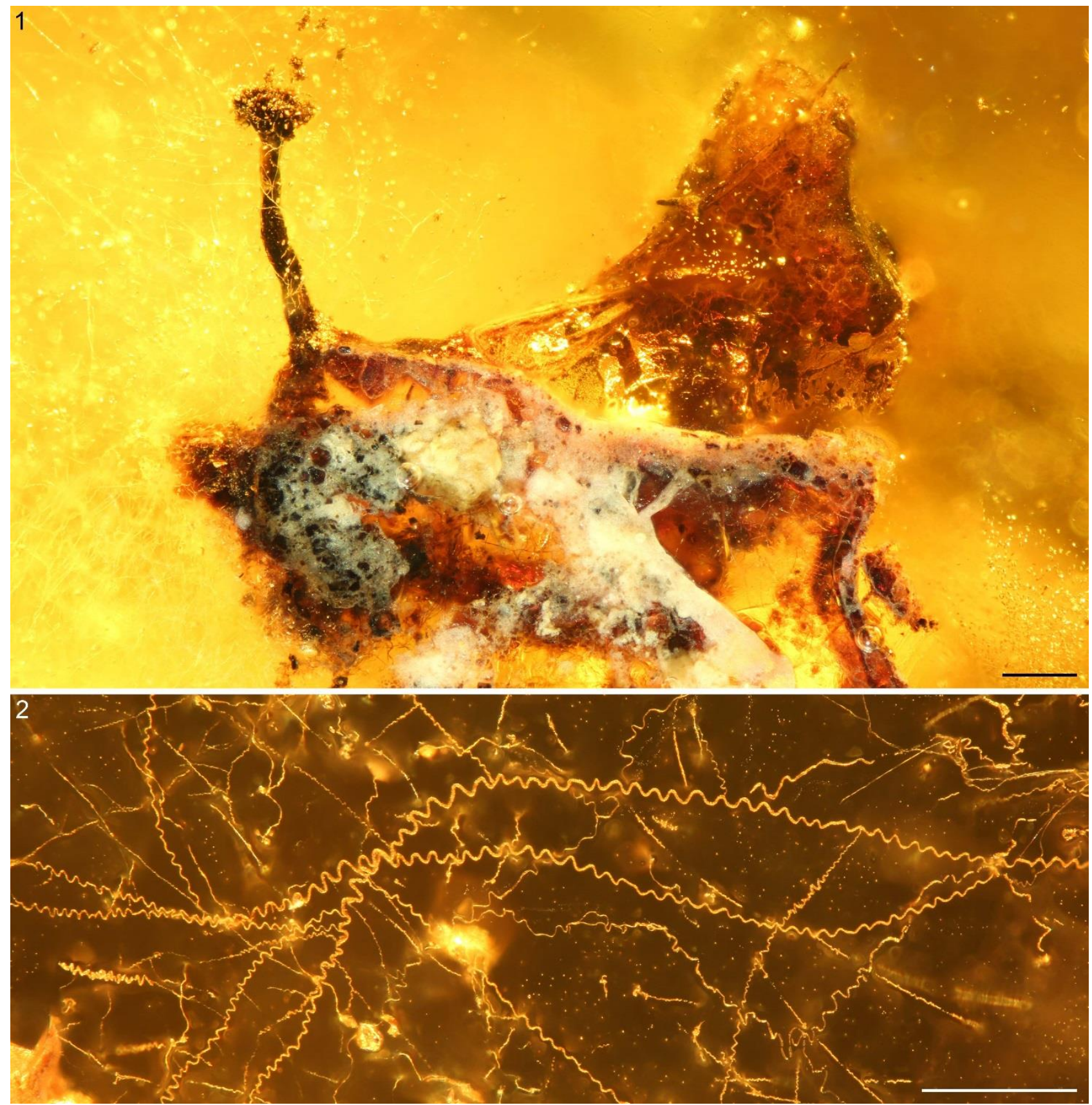

Plate VI. Chaenothecopsis bitterfeldensis in Bitterfeld amber. 1. The fungus had produced an extensive mycelium over an old resin surface, partly superficial and penetrating into the substrate. Ascomata emerge from the dense hyphal mat, and many detached ascospores occur in the surrounding amber matrix (George O. Poinar Amber Collection, AF 926). 2. The resin substrate of the fungus is completely infested with hyphae, often with spirally twisted regions (Heinrich Grabenhorst Amber Collection, Le-127). Scale bars $=200 \mu \mathrm{m}$. 

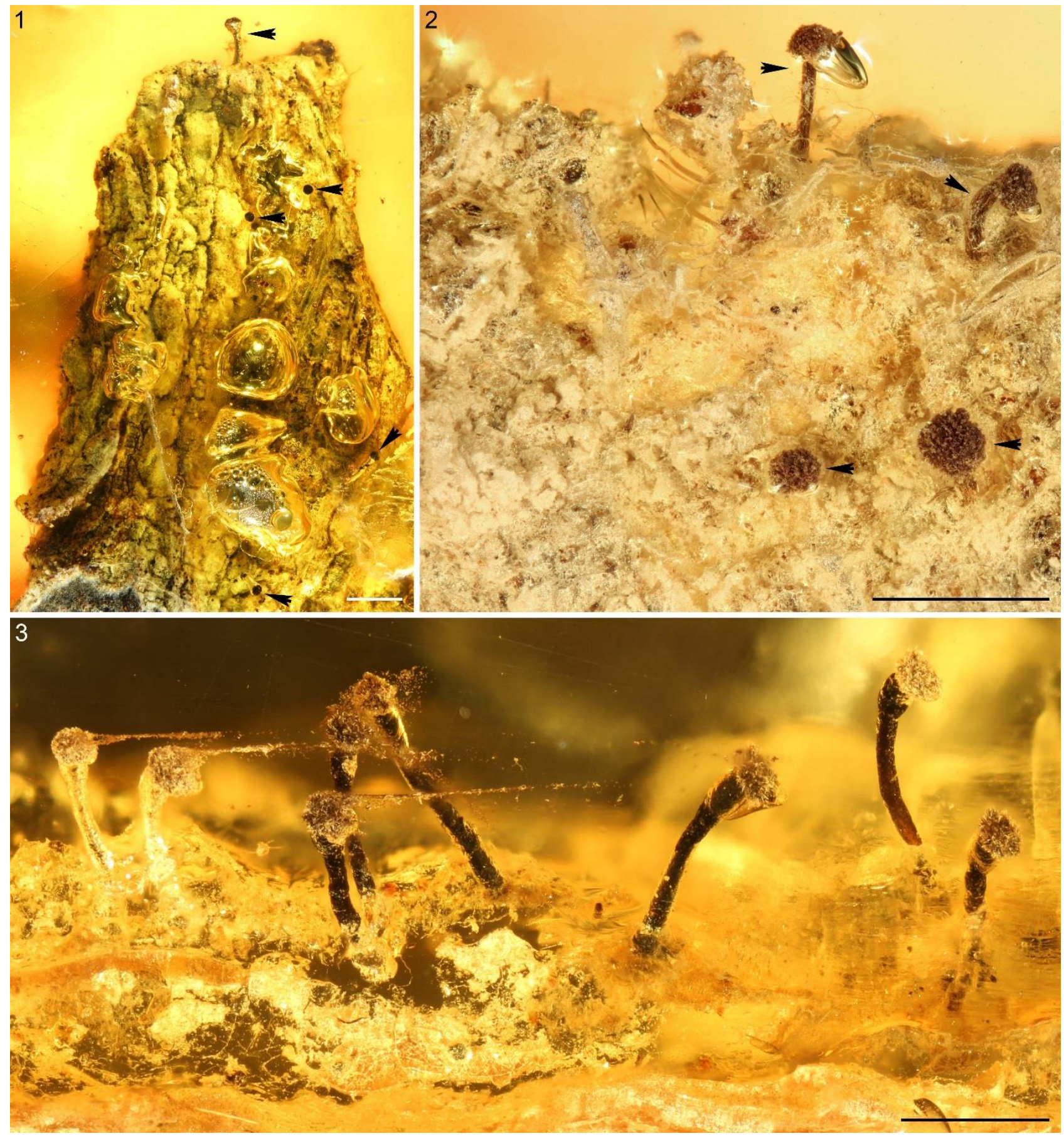

Plate VII. Morphology of fossil calicioid lichens of the genus Chaenotheca. 1. Chaenotheca sp. in Baltic amber (Geoscientific Collections of the University of Göttingen, GZG.BST.27297). Note verrucose thallus covering substrate and several ascomata (arrowheads). 2. Chaenotheca sp. in Baltic amber (Max Kobbert Amber Collection, sine numero). Note coarsely granular to minutely squamulose thallus on substrate and four ascomata with well-developed mazaedia (arrowheads). 3. Chaenotheca succini in Baltic amber (Carsten Gröhn Amber Collection, P 5377). Scale bars $=500 \mu m$. 

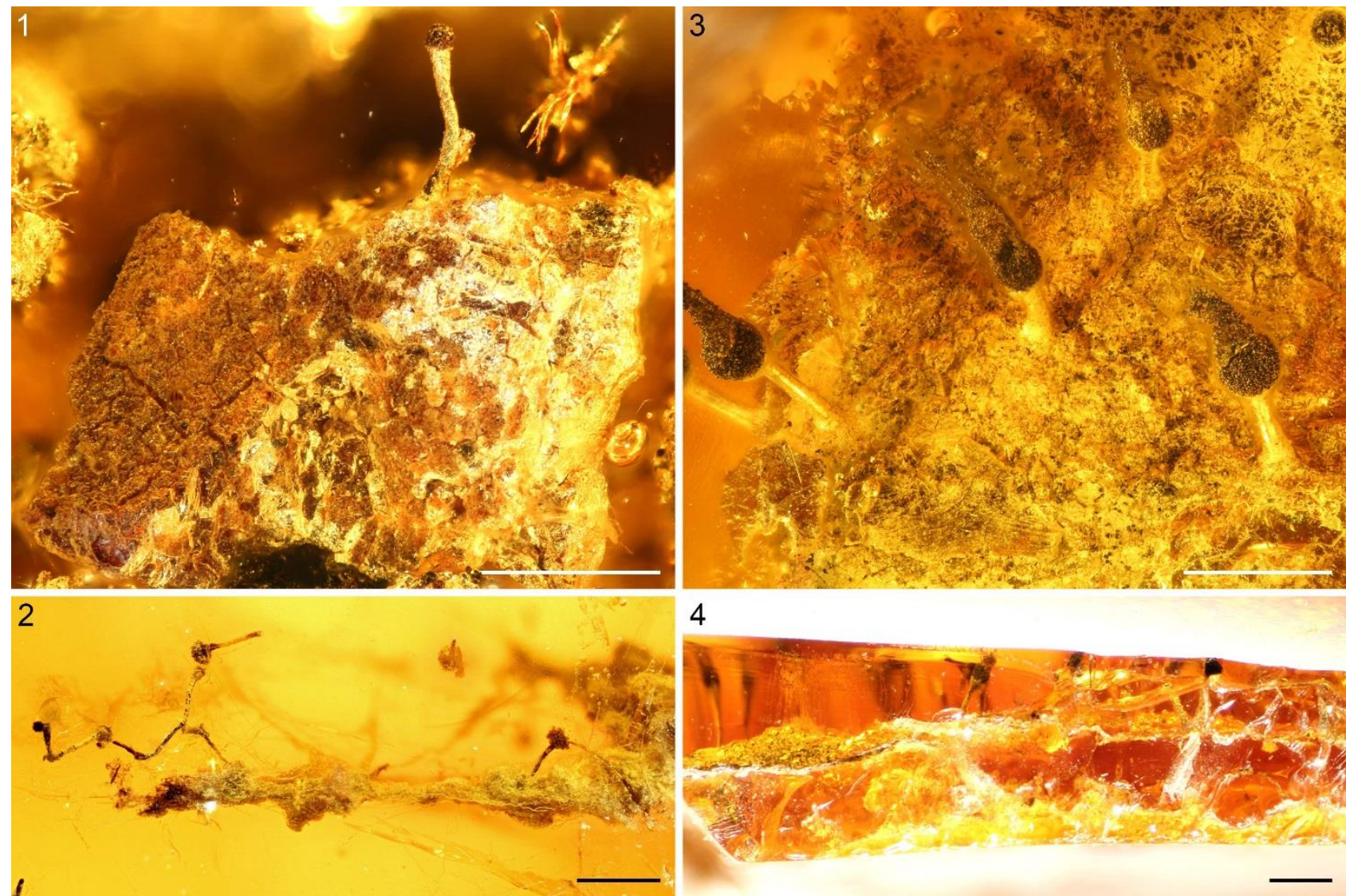

4

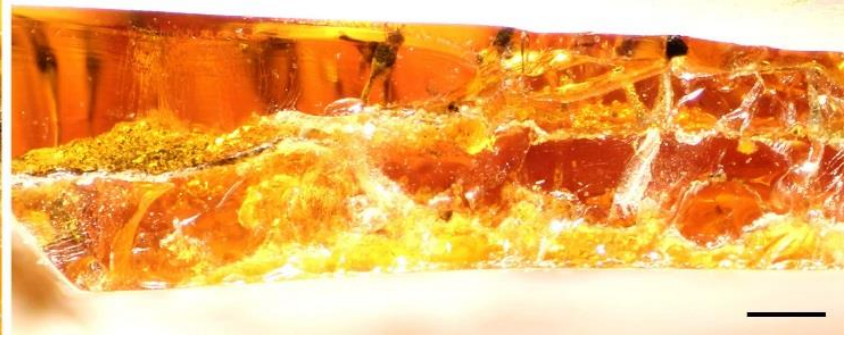

Plate VIII. Preservation of fossil calicioid lichens and fungi in amber. 1. A small detached resin fragment with a single ascoma of Chaenotheca sp. attached is preserved together with bark fragments, stellate plant hairs and other debris in Bitterfeld amber (Grabenhorst Amber Collection, Le-75). 2. Ascomata of Chaenothecopsis cf. bitterfeldensis, some attached to mycelium and others caught in an overlying spider web preserved in Bitterfeld amber (Grabenhorst Amber Collection, Mi-55). 3. Ascomata of Calicium cf. succini in Bitterfeld amber (Geoscientific Collections of the University of Göttingen, GZG.BST.27300). Mature ascospores were organized into elongated fans in the amber matrix after being pulled from the mazaedium by a slow and unidirectional flow of resin. 4. Piece of Bitterfeld amber composed of three successive resin flows that preserved ascomata of Calicium cf. succini (Geoscientific Collections of the University of Göttingen, GZG.BST.27300). Scale bars $=500 \mu \mathrm{m}$. 

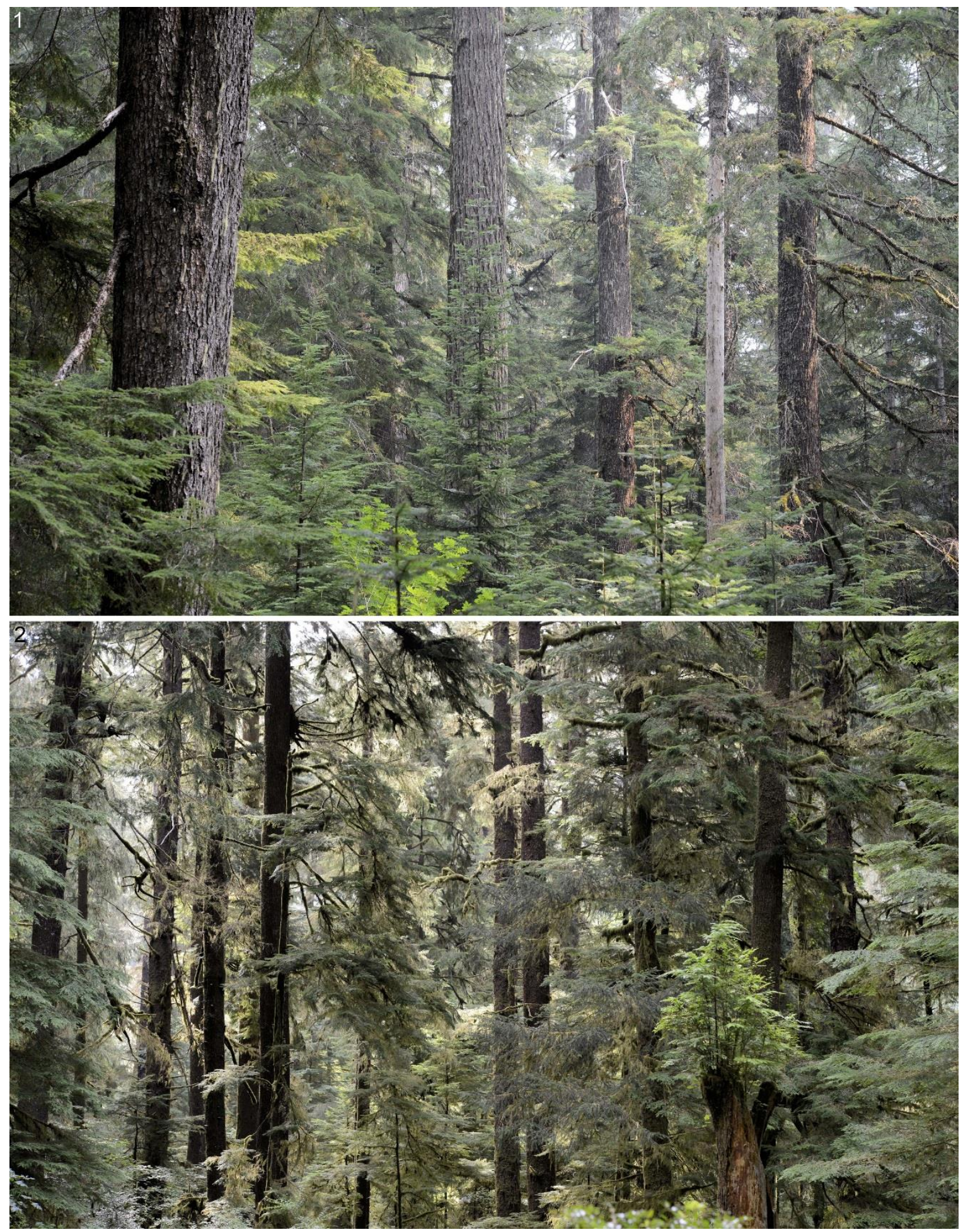

Plate IX. Relationship between forest structure and calicioid diversity in extant temperate conifer forests as illustrated by two surveyed forest stands in western Oregon (data from Rikkinen 2003a). 1. Old-growth mixed conifer forest in Hackleman Grove in the Cascades. Mixed montane conifer forests of suboceanic and subcontinental temperate regions represent an optimal habitat for many calicioid lichens and fungi. This is because they offer a wide range of microhabitats that combine favorable light conditions with high atmospheric humidity and also an abundant supply of hard lignum. Consequently, both calicioid diversity ( 26 species found) and the overall abundance of dominant species are relatively high. 2. Old-growth Sitka spruce forest in Cummins Creek in the Coast Range. Temperate rainforests represent a suboptimal habitat for most calicioid lichens and fungi and consequently species diversity (13 species found) and the overall abundance of dominant species are relatively low. The reasons for this include excessive humidity and shading, the lack of hard lignum, competition for space by bryophytes, and intense mollusk grazing. 

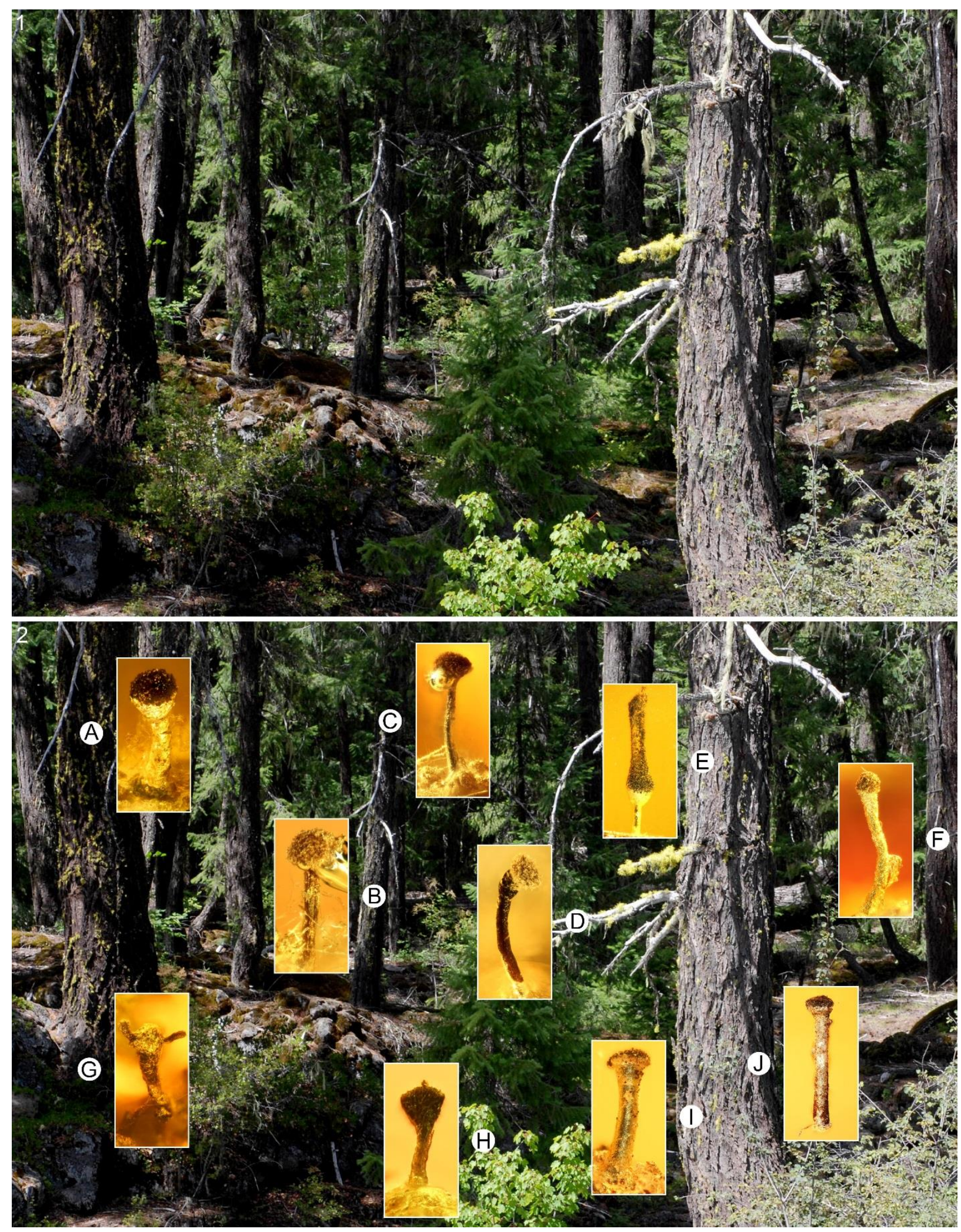

Plate X. Many extant calicioid lichens and fungi in temperate forests have specialized habitat requirements. They represent an important functional group in old-growth forests where diverse communities are found in humid microhabitats that receive plenty of diffuse light, but not much direct sunlight. As the abundance and diversity modern calicioids is climate and habitat dependent, and as the calicioids in amber probably exhibited congruent habitat preferences, the fossils provide rare insights into the habitat quality. 1 . On the basis of what is known about the ecological requirements of extant calicioids we propose a model of a forest stand where all the known fossil 
specimens could have existed side by side. The reconstruction is based on an extant humid-temperate mixed conifer forest from the Oregon Cascades, western North America. 2. Within the habitat model we indicate a possible microhabitat for all fossil specimens so far found from European Paleogene amber. A. Chaenotheca sp. (Baltic amber, Geoscientific Collections of the University of Göttingen, GZG.BST.27297). B. Chaenotheca sp. (Baltic amber, Max Kobbert Amber Collection, sine numero). C. Chaenotheca sp. (Baltic amber, Carsten Gröhn Amber Collection, P 6463). D. Chaenotheca succini (Baltic amber, Carsten Gröhn Amber Collection, 5377). E. Calicium cf. succini (Bitterfeld amber, Heinrich Grabenhorst Amber Collection, Li-22). F. Chaenotheca sp. (Bitterfeld amber, Heinrich Grabenhorst Amber Collection, Le-75). G. Chaenothecopsis cf. bitterfeldensis (Baltic amber, Jörg Wunderlich Amber Collection, F2026). H. Phaeocalicium sp. (Bitterfeld amber, Heinrich Grabenhorst Amber Collection, Le-10). I. Calicium succini (Baltic amber, Museum für Naturkunde zu Berlin, MB.Pb.1979/838). J. Calicium sp. (Baltic amber, GZG.BST.27296). 